\title{
Foreclosure Externalities and Vacant Property Registration Ordinances
}

\author{
Arnab Biswas, Chris Cunningham, \\ Kristopher Gerardi, and Daniel Sexton
}

\section{Working Paper 2019-20 \\ November 2019}

\begin{abstract}
This paper tests the effectiveness of vacant property registration ordinances (VPROs) in reducing negative externalities from foreclosures. VPROs were widely adopted by local governments across the United States during the foreclosure crisis and facilitated the monitoring and enforcement of existing property maintenance laws. We implement a border discontinuity design combined with a tripledifference specification to overcome policy endogeneity concerns, and we find that the enactment of VPR0s in Florida more than halved the negative externality from foreclosure. This finding is robust to a rich set of time-by-location fixed effects, limiting the sample to properties within 0.1 miles of a VPR0/non-VPRO border and to a number of other sample restrictions and falsification exercises. The results suggest that an important driver of the negative price effect of nearby foreclosures is a nonpecuniary externality where the failure to maintain or secure a property affects one's neighbors.
\end{abstract}

JEL classification: H23, K25, R52, R28

Key words: mortgage default, foreclosure, externality, policy, vacancy

https://doi.org/10.29338/wp2019-20

The authors thank Scott Frame, Tony Yezer, Paul Calem, Lauren Lambie-Hansen, Nikodem Szumilo, and seminar participants at the University of Cincinnati, Katholieke Universiteit Leuven, Cambridge University, University of Florida, and conference participants at the AREUEA National meeting in Washington DC, the Urban Economics Association meeting in Amsterdam, the Federal Reserve System meeting in Pittsburgh, and the National Tax Association meeting in Tampa Bay for valuable comments and suggestions. They also thank the Federal Reserve Bank of Atlanta Center for Housing and Policy for support and Dan Immergluck for collecting the ordinances. The views expressed here are those of the authors and not necessarily those of the Federal Reserve Bank of Atlanta or the Federal Reserve System. Any remaining errors are the authors' responsibility.

Please address questions regarding content to Arnab Biswas, University of Wisconsin-Stout, 440D Harvey Hall, 712 South Broadway Street, Menomonie, WI 54751, biswasa@uwstout.edu; Chris Cunningham, Research Department, Federal Reserve Bank of Atlanta, 1000 Peachtree Street NE, Atlanta, GA 30309-4470, chris.cunningham@atl.frb.org; Kristopher Gerardi, Research Department, Federal Reserve Bank of Atlanta, 1000 Peachtree Street NE, Atlanta, GA 30309-4470, kristopher.gerardi@atl.frb.org; and Daniel Sexton, Research Department, Federal Reserve Bank of Atlanta, 1000 Peachtree Street NE, Atlanta, GA 30309-4470, daniel.sexton@atl.frb.org.

Federal Reserve Bank of Atlanta working papers, including revised versions, are available on the Atlanta Fed's website at www.frbatlanta.org. Click "Publications" and then "Working Papers." To receive e-mail notifications about new papers, use frbatlanta.org/forms/subscribe. 


\section{Introduction}

There were more than 4 million residential property foreclosures completed between the start of the Global Financial Crisis in September of 2008 and the end of 2012 1 The foreclosure crisis had detrimental effects on local housing markets. A growing body of literature has provided empirical evidence that foreclosures exert significant negative externalities on nearby home values (Immergluck and Smith (2006); Schuetz et al. (2008); Harding et al. (2008); Lin et al. (2009); Rogers and Winter (2009); Campbell et al. (2011); Biswas (2012); Anenberg and Kung (2014); Gerardi et al. (2015)). The existence of foreclosure spillovers has been used to justify, in part, a number of government interventions into housing and mortgage markets, including HAMP (Home Affordable Modification Program) and HARP (Home Affordable Refinancing Program), the Neighborhood Stabilization Program (NSP), and additional regulation of mortgage products as part of the Dodd-Frank Act (2010).

Despite these interventions, the exact nature of foreclosure-related externalities remains unclear. While a consensus has emerged on the existence of price spillovers from foreclosures, there remains considerable debate about the mechanism through which this occurs. There are three plausible channels that the literature has identified. First, homes sold via a foreclosure auction could create low comparable sale prices that may adversely affect the value of non-distressed properties. Second, foreclosures may increase competition in a market resulting in lower transaction prices for non-distressed properties ${ }_{2}^{2}$ Finally, homes that are or will soon be foreclosed upon, may become sources of visual blight or environmental hazards and attract crime and vandalism, which in turn may adversely affect the quality of life for households in the same neighborhood. Those distressed properties, therefore, through vacancy and neglect by both borrowers as well as mortgage lenders, may reduce the value of nearby non-distressed properties 3

The distinction between these different causal mechanisms is important from a policy perspective. Standard economic theory makes a crucial distinction between price effects caused by technological or physical externalities, so-called "non-pecuniary" externalties, versus those caused by supply and demand shocks, socalled "pecuniary" externalities, which simply shift surpluses from sellers to buyers (or vice-versa). The first two mechanisms described above are examples of pecuniary externalities, as the pricing spillover effects are driven by the timing and nature of the foreclosure sales 4 The third mechanism discussed above, visual

\footnotetext{
${ }^{1}$ CoreLogic Foreclosure Report, December 2012: https://www.corelogic.com/news/corelogic-reports-767000-completedforeclosures-in-2012.aspx

2 Anenberg and Kung (2014) provide evidence of this "supply effect" as they document that sellers decrease their listing prices in the same week that nearby bank-owned (REO) properties are listed in the San Francisco, Washington D.C., Chicago, and Phoenix housing markets during the 2007-2009 period.

3 Gerardi et al. (2015) find evidence of such a physical externality using data on the 15 largest U.S. housing markets during the 2001-2010 period. The paper finds that the size of the negative price spillover from nearby foreclosures is sensitive to the physical condition of the distressed properties as REO properties in relatively poor condition lower the prices of nearby nondistressed transactions by significantly more than REO properties in better condition. Fisher et al. (2015) also find evidence of a physical externality using a sample of condominiums in Boston.

${ }^{4}$ We may still care about these pecuniary externalties in this context because during a foreclosure crisis they may increase
} 
blight leading to vagrancy and/or crime, affects all nearby residents and not just the seller and buyer. This mechanism is an example of a non-pecuniary externality, which results in deadweight loss and thus warrants public intervention.

Motivated by this latter concern, a number of U.S. cities passed Vacant Property Registration Ordinances (VPRO)s in the aftermath of the mortgage foreclosure crisis, which require mortgage lenders to notify the local government when they initiate the foreclosure process. VPROs can ameliorate the negative spillovers from foreclosure in two ways. First, the local government can monitor the property for any code violations and if necessary, intervene. Second, in most cases, the foreclosing lender becomes liable for any code violations, even before it formally takes possession of the property, insuring that the home remains secure and in good repair.

The goal of this paper is to determine whether these VPROs were effective in mitigating the negative physical exernalities from foreclosures. Despite a growing number of studies that have documented the existence and magnitude of foreclosure externalities, rigorous analyses of local housing policies that aim to mitigate those externalities are largely absent from the literature. To our knowledge, this paper is the first to evaluate the effect of VPROs in a systematic manner. We specifically analyze whether VPROs enacted in the state of Florida during the late 2000s were successful in stabilizing home prices using a hedonic regression framework common in the foreclosure spillover literature. This involves estimating hedonic pricing regressions with a rich set of geographic and time fixed effects (similar to specifications used by Campbell et al. (2011) and Gerardi et al. (2015) ) using property transactions data from Florida, and allowing the effect of nearby foreclosures to vary in a triple differences framework. Essentially, we compare how the difference in foreclosure spillover effects between municipalities that passed VPROs and those that did not (non-VPRO cities) changed after the VPROs were enacted.

The obvious challenge of using legislative changes to identify causal treatment effects is policy endogeneity. In this context, the concern is that municipalities that were impacted the most by the foreclosure crisis may have been more likely to pass a VPRO compared to cities that were not as adversely affected. In the absence of a compelling instrument, we instead employ a border discontinuity design that matches properties in VPRO cities to homes in adjacent non-VPRO municipalities that are close to the respective boundaries.

Consistent with previous findings in the literature, controlling for basic property characteristics and a rich set of geographic and time fixed effects, we find that each additional property in the foreclosure process within 0.1 miles of a non-distressed property at the time of transaction lowers the sales price by approximately 1 percent. Before the enactment of the VPRO, nearby foreclosures on both sides of the border have similar

the risk of large-scale price declines and lead to fire-sales, which could amplify the crisis and adversely affect mortgage markets, broader financial markets, and the overall economy. 
negative price effects. After the enactment of the VPRO, the negative estimated externality more than doubles for property sales taking place on the non-VPRO side of the border. The increase in the externality is likely due to the worsening of the foreclosure crisis and the growing backlog of foreclosed properties in the state. In contrast, the estimated negative externality does not change for transactions taking place on the VPRO side of the border, which suggests that the VPRO enactment significantly mitigated foreclosure externalities in Florida.

We show that these results are robust to several different sampling, econometric, and measurement assumptions including different distance to the border thresholds (from 0.1 miles all the way up to 3 miles), restricting the sample to borders with a high number of transactions (at least 200 on each side), several different perturbations to the set of fixed effects included in the hedonic regressions, and redefining nearby foreclosures to only include lender-owned (REO) properties. In addition, we show that the parallel trends assumption is satisfied in our context, as there are no discernible differences in foreclosure externality trends between VPRO and non-VPRO municipalities leading up to enactment. Finally, we conduct a pair of falsification exercises. First, we estimate our primary specification using false borders in geographic space. Specifically, we assume the borders are one mile inside of the VPRO municipalities, and then compare the change in foreclosure externalities for VPRO sales on each side of the fake border. Second, we assume that the VPROs were passed two years prior to the actual enactment dates, and re-estimate our primary specification for property sales that occurred in a two-year window around the fake dates. In both cases we do not find evidence of a positive VPRO treatment effect.

Finally, we present evidence that the VPROs increased the values of foreclosed properties themselves. We implement a triple-difference estimator that compares how the difference in sale prices between REO and non-distressed properties between VPRO and non-VPRO municipalities changed after the VPROs were enacted. The estimation results imply that VPROs raised REO sale prices by $5-10 \%$, which is consistent with our interpretation that the ordinances mitigated physical foreclosure externalities by improving property maintenance and preventing excessive depreciation.

Our paper makes two important contributions to the literature. It provides the first estimates of the effectiveness of the most important policy implemented by local governments to combat the foreclosure crisis. According to our data, more than 500 municipalities across the U.S. have enacted VPROs within the last two decades. We provide evidence that these policies do significantly mitigate foreclosure externalities. Second, our results yield insight into the mechanisms driving the foreclosure price spillovers that have been previously documented in the literature. VPROs are designed to prevent the rapid depreciation of properties owned by financially distressed borrowers and mortgage lenders. The laws require the formal registration of foreclosed properties, and typically require mortgage lenders to secure and maintain those properties. 
Thus, they are specifically intended to target the physical externality caused by foreclosures. Our results showing that they do in fact significantly ameliorate price spillovers, suggests that the physical externality is economically important.

The rest of the paper proceeds as follows: In Section 2 we review the institutional details of VPROs. In Section 3 we describe the data used in the analysis, which include arms-length home sales obtained from public records and VPRO enactment details at the municipality level from a proprietary dataset. Section 4 details our econometric strategy, while Section 5 reports the main estimation results. We present a series of robustness checks and falsification exercises in Section 6. In Section 7) we test for VPRO effects on REO sale prices. Finally, Section 8 provides a brief conclusion with a discussion of the policy implications of our analysis.

\section{Background and Data on VPROs}

In the wake of the recent mortgage crisis, many local municipalities around the country passed VPROs in an attempt to limit the negative spillovers from foreclosed and vacant homes on neighborhoods. Foreclosed properties are generally characterized as vacant, abandoned, and dilapidated buildings that often create an eyesore or result in increased crime and vandalism. Disinvestment that leads to physical deterioration of the property is arguably present both during the foreclosure process and when the property becomes repossessed by the mortgage lender (Gerardi et al. (2015)). This "disamenity" effect is believed to lower the value of nearby properties by driving away potential buyers and to lower the utility of current residents. VPROs enable cities to track the owners or lien holders of those vacant or foreclosed properties through a registration database maintained by the local government. The main purpose of VPROs is to ensure that the registered owners and lien holders are informed about their obligations under the relevant codes and regulations with respect to maintaining and securing their vacant properties.

Our information about VPROs comes from Lee et al. (2013), which compiled a national database of VPROs enacted through April 2012 5 The database includes information on the enactment date and the municipality that passed each ordinance. The data also include some basic characteristics of each VPRO, including the trigger mechanism, the fine schedule and other consequences for not complying with the VPRO, maintenance requirements, and information on the frequency of inspections by local government officials.

The number of VPROs adopted nationwide increased from 87 just before the foreclosure crisis to 550 by May 2012, according to Lee et al. (2013). We focus on a single state in this analysis in order to avoid the large amount of cross-state heterogeneity that exists in foreclosure laws. Many states have judicial foreclosure

\footnotetext{
${ }^{5}$ We thank Dan Immergluck for providing the raw data.
} 
processes, while others have non-judicial processes 6 But even within the set of judicial foreclosure states, there can be large differences in the details of the process, which generate significant differences in average foreclosure timelines across states 7

We focus specifically on the state of Florida for three reasons. First, Florida municipalities enacted numerous VPROs during our sample period. Starting with no ordinances in 2007, by early 2012, $83 \mathrm{mu}-$ nicipalities in the state had enacted a VPRO 8 Altogether, Florida accounts for approximately $15 \%$ of the VPROs enacted in the country during our sample period. Second, Florida is a judicial foreclosure state, with well-documented, lengthy foreclosure timelines that may have exacerbated the physical externalities from foreclosures 9 Third, in Florida the court system is operated at the county level, and the county court is the entity with the authority to strip a borrower of his or her property title. In addition, Florida's school districts are coterminous with county boundaries so that K-12 education, jails, and infrastructure as well as the associated property taxes do not vary within a county. Florida's cities, on the other hand, provide fewer services-maintaining local streets, sidewalks and parks, often police services, and sometimes fire, sanitation and library services. However, critical of our analysis, cities always retain responsibility for zoning and code enforcement and thus generate relatively fine variation in the location and timing of VPRO enactment.

The top panel of Table 1 displays the number of Florida VPROs enacted by year and shows the type of mechanism that triggers the VPRO. There are two types of triggers that can force a lender to register the property under a VPRO. One occurs when the property is abandoned and becomes vacant. A second trigger is when the lender begins the foreclosure process. There are also some VPROs that require both foreclosure and vacancy to trigger. While the vacancy ordinances trigger registration after a certain length of vacancy by the former owner, foreclosure-related ordinances are triggered by the notice of default or intent to foreclose issued by the lender. In Florida, about 58 percent of the localities that enacted a VPRO adopted this joint threshold for registration (48 out of 83) while the remainder required either vacancy or default to trigger. Since we do not observe vacancy status in our data, we rely exclusively on the foreclosure process to identify exposure to the VPRO requirements. In a robustness check we limit the analysis to REO properties only, since we are certain that they are vacant, and show that our results continue to hold.

In order to discourage irresponsible investment or unproductive use of properties, VPROs often resort to a periodic registration fee structure. In Florida, most of the localities that have adopted VPROs require annual registration. The registration fee may go up if the property remains vacant for an extended period.

\footnotetext{
${ }^{6}$ For a comprehensive list of judicial versus non-judicial states, see Rao and Walsh 2009 .

${ }^{7}$ See Cordell et al. (2015) for a detailed analysis of differences in foreclosure timelines between judicial and non-judicial states. Gerardi et al. (2013) provides summary statistics on the distribution of state-level foreclosure timelines during the financial crisis period (see Table 1 in the paper).

${ }^{8}$ California was the only state that added more during this period, going from 4 in 2007 to 90 in 2012.

${ }^{9}$ According to Gerardi et al. (2013) Florida had one of the longest average foreclosure timelines during the crisis period (see Table 2 in the paper).
} 
If requirements are not met (for example, failing to register the vacant properties in a timely manner), most VPROs impose fines and, in some cases, administrative actions on the lenders. The bottom panel of Table 1 displays the number of Florida VPROs that impose fines on lenders for not registering their properties. The majority impose a fine between $\$ 250$ and $\$ 500$. In addition, about 20 percent of VPROs in Florida allow for charging a property owner with a criminal misdemeanor for not registering.

Although the details of these ordinances vary, the common theme among all of them is to prevent neighborhood destabilization by increasing carrying costs of unoccupied properties while holding lenders accountable for poor maintenance. Most VPROs require the lender to secure the building against entry and to regularly check on the property. In addition, most Florida VPROs require lenders to post contact information so that neighbors can easily report security or maintenance problems. Lenders are also expected to maintain the property. For example, most Florida cities require the lender to clean up the grounds, prevent graffiti, and maintain landscaping and pools. Finally, most VPROs involve periodic inspections by local officials. According to Table 1 about 80 percent of Florida VPROs involve inspections that are at least monthly.

\section{Data}

Our primary dataset consists of the universe of single-family residential property transactions in the state of Florida from 2006 through 2013, which come from a database of property records provided by CoreLogic. For our principal hedonic specification, we match each property sale to a set of property characteristics including lot size, livable area, number of bedrooms, number of bathrooms and age. These data are collected and harmonized by CoreLogic from county assessors and deed registrars. The dataset includes the latitude and longitude of each land parcel, which allows us to determine the city, census tract, and county in which each property is located, as well as the distance between any two properties in our sample. We include only arms-length transactions of single family residences in incorporated areas of Census Bureau Statistical Areas (CBSAs) with more than 10,000 sales over the sample period. Sales in our sample also meet exactly one of the following criteria: they are in a jurisdiction that has ever enacted a VPRO, or they are in a jurisdiction that borders another jurisdiction that has ever enacted a VPRO. We also maintain balance between the counts of VPRO and non-VPRO sales on each side of a border by retaining only the borders in which between one-quarter and three-quarters of the total number of sales for that border occurred in the VPRO region.

To eliminate outliers, we exclude homes that are sold in the bottom 1 percent and above the 98 th percent of the price distribution (selling for below $\$ 22,000$ and above $\$ 957,000$, respectively). We also exclude homes with more than 6 bedrooms or 6 bathrooms (approximately 1 percent of the sample) and winsorize lot size 
and living area values below the bottom 1 percentile and above the top 99th percentile.

Summary statistics for our sample of sales are displayed in Table 2. Columns (1)-(4) present the mean, standard deviation, minimum and maximum for our sample of arms-length home sales within 1 mile of a VPRO/Non-VPRO border. We display statistics for the price and the hedonic characteristics included in our analysis. Columns (5) and (6) provide the mean and standard deviation for the subset of properties that occur in cities that pass a VPRO during our sample period while columns (7) and (8) provide them for cities that do not.

Note that homes in jurisdictions that implement VPROs are smaller, are located on smaller lots, and sell for less. We will control for a rich number of fixed effects in addition to basic property characteristics so that we can isolate variation that might co-move with prices and foreclosures. Central to this strategy will be to pair properties on either side of the border and include border fixed effects in the regression specifications. Table A.2 in the Online Appendix shows that at our finest buffer distance, 0.1 miles, we are able to eliminate statistical differences in means but, this comes at the expense of losing a significant number of observations (about 80 percent). For the majority of our analysis we will focus on property transactions that are within 0.5 miles from a VPRO/non-VPRO border. At a distance threshold of a half mile we retain almost 30,000 property transactions, which is a large enough sample to allow for a fairly saturated set of geographic and time fixed effects. At closer distances we lose significant chunks of our sample, and thus, begin to sacrifice power. However, we will show how our empirical results change as we vary the distance threshold to the borders.

As the underlying data on property characteristics comes from the tax assessors' offices, some variables, especially features internal to the home such as the number of bedrooms and bathrooms, are missing. In our regression analysis, we include separate dummy variables for missing values and re-code the missing values as zeroes.

\subsection{Foreclosure Data}

Our analysis requires information on the number of properties in the foreclosure process in close proximity to all of the property sales in our data. We follow the literature and focus on the count of properties in the foreclosure process within a very close radius $(0.1$ miles) of each sale (e.g., both Campbell et al. (2011) and Gerardi et al. (2015) focus on a radius of 0.1 miles). We obtain information on foreclosures from CoreLogic, which provides information on lis pendens (the first notification of the start of foreclosure action), final judgments (the court's decree in regards to the foreclosure), and certificates of title (the transfer of the property to the new owner, which is only available in Florida). We also use information from the 
CoreLogic property transactions database, which includes foreclosure deeds. The foreclosure deed coincides with the certificate of title and serves to denote the very end of the borrower's ownership of the property. Typically, this coincides with the start of the Real Estate Owned (REO) period when the mortgage lender takes possession of the property and attempts to sell it to another buyer. In the minority of cases where the foreclosure auction is successful and the mortgage lender does not possess the property, it will coincide with a new, non-distressed ownership spell.

For the purposes of creating our nearby foreclosure variables, we define the foreclosure process as starting with the lis pendens and ending when the property is sold to a non-bank entity. Thus, our measure of foreclosure spans the period in which a property is in the judicial foreclosure process and the REO period, if applicable 10

For all specifications, we measure a given non-distressed sale's exposure to the foreclosure externality by counting the number of properties within 0.1 miles that are in the foreclosure process (i.e., between the filing of the lis penden and the sale out of REO to a non-bank entity). Figure 3 illustrates the window of time that a given property is treated as being in foreclosure. The bottom panel of Table 2 displays information on the count of foreclosures within 0.1 miles of the property sales in our sample. Almost three-quarters of the properties in our sample have at least one nearby foreclosure at the time of sale. On average, property transactions have approximately three nearby properties in some stage of the foreclosure process.

\subsection{Border Pairs}

In addition to a rich set of time and location fixed effects, our primary identification strategy is to use municipal borders and the timing of enactment to isolate plausibly exogenous variation in exposure to a VPRO ordinance. A key challenge is that cities suffering from a foreclosure crisis will be more likely to pass these ordinances. To overcome this policy endogeneity we limit the sample to homes that are close to a $\mathrm{VPRO} /$ non-VPRO border. The idea is that whatever is causing the foreclosure crisis to be more acute in one area is attenuating smoothly across municipal borders. For example, a central city may have a high-poverty neighborhood that experienced a large number of foreclosures and spillovers, creating a strong political demand for an ordinance. However, at the edge of the city, the neighborhoods may have experienced fewer foreclosures and look quite similar to the adjoining neighborhood in a city that never enacted a VPRO. In that case, the policy treatment of a VPRO may be effectively exogenous from the perspective of those particular neighborhoods.

\footnotetext{
${ }^{10}$ It is important to note again that we do not have information on the vacancy status of a property in the foreclosure process. Our implicit assumption in our baseline specifications is that VPROs apply to all properties in any stage of the foreclosure process, as defined above. In a robustness check below, we will recalculate our nearby foreclosure variable to only include properties that are REO at the time of sale, as we can be sure that REO properties are vacant.
} 
We match sold homes on either side of a border and create a common boundary identifier. We then use this new geographic identifier to create additional location and location-by-time fixed effects to control for any common location specific variation in prices that might confound our estimates. A close up of paired sales, denoted by color, is presented in Figure $2^{11}$ The average border pair contains 873 sales, but this number is skewed by several large borders. The median border pair has 435 sales, and some pairs are so small that they are completely absorbed by the fixed effects. In a robustness check, we exclude border pairs with less than 200 sales.

\section{Econometric Framework}

We begin our analysis by testing for foreclosure price spillovers in our sample of Florida property sales. While many previous studies have documented significant negative spillovers, none to our knowledge have done so using data from Florida. A common strategy for measuring a foreclosure spillover is to include a measure of foreclosure exposure in a hedonic house price regression ${ }^{12}$ A negative coefficient estimate indicates that potential buyers have a reduced willingness to live near such properties that is then capitalized into market values.

The central challenge to identify a negative externality or spillover effect from foreclosure is the simultaneity in house price declines and foreclosures. Indeed, a decline in prices is usually a necessary condition for foreclosure, and thus, simply observing a rise in foreclosures and decline in prices in a given area isn't itself compelling evidence for the existence of a spillover. In addition, unobserved local supply and/or demand shocks, such as a negative shock to local labor markets, could generate both a decline in prices and increase in foreclosures, resulting in endogeneity bias.

To overcome this simultaneity problem, previous papers have included very fine geographic and time fixed effects. The identifying assumption is that within a small enough area, such as a census track or block group, the location and timing of foreclosures are effectively random. We follow this existing literature in setting up our baseline specification. We include a parsimonious set of control variables for house and lot size (in natural logs), home age as a fourth order polynomial (quartic), the number of bedrooms and bathrooms, and dummy variables for homes with only one bedroom or one bath (as households without children are more likely to live in these). In addition, we include dummies for missing values ${ }^{13}$ We also include a rich

\footnotetext{
${ }^{11}$ We create border identifiers by incrementally buffering cities and census designated places in 50 foot increments using the GIS software MapInfo/MapBasic version 16.0.

12 Alternatively, some papers employ a repeat-sales estimator (Harding et al. (2007) and Gerardi et al. (2015). While such an estimator is appealing for many reasons, it requires a sample of properties that sell multiple times in the sample period. This would dramatically reduce our sample of Florida properties and would not allow us to to implement our triple difference, border-matching identification strategy.

${ }^{13}$ The number of bedrooms and bathrooms is often not known by the county assessor's office.
} 
set of fixed effects for both time and location that we progressively add to the specification. Formally, our basic econometric specification is given by:

$$
\ln \left(P_{i j t}\right)=\eta_{t}+\mu_{j(t)}+\gamma X_{i t}+\theta F C_{i t}+\varepsilon_{i j t}
$$

where $P_{i j t}$ is the transaction price for property $i$ in geography $j$ sold in time period $t . X_{i t}$ is the vector of house characteristics described above, $\eta_{t}$ corresponds to calendar year fixed effects, $\mu_{j}(t)$ represents geographic fixed effects, (county or census tract) that are, in some specifications, interacted with year dummies ${ }^{14}$ The effect of proximate foreclosures on sales price is captured by the coefficient $\theta$ associated with the number of properties in the foreclosure process within 0.1 miles of the reference property sale, $F C_{i t}$. Finally, $\varepsilon_{i j(t)}$ is a standard residual which we estimate using robust standard errors clustered at the border-pair level 15

One of the primary challenges in evaluating the efficacy of a VPRO is endogenous policy formation. Cities that are suffering from a foreclosure crisis may be more likely to pass a VPRO and this could create a bias that would work against finding a beneficial effect from the ordinance. Indeed, we observe in Table 2 that property sales in VPRO municipalities had greater exposure to foreclosures than those in non-VPRO cities. This is even more apparent in Table A.2 of the Online Appendix. Taking a buffer of three miles on either side of VPRO/non-VPRO boundaries reveals that homes in VPRO cities are on significantly smaller lots. This higher density mechanically increases the potential number of homes within 0.1 miles that are in foreclosure. Similarly, homes in VPRO cities are on average three years older than those in non-VPRO areas. If older homes require more maintenance they may deteriorate more quickly when vacant. We attempt to control for this by matching homes on either side of a VPRO/non-VPRO border and limiting the sample to sales relatively close to the border. The identifying assumption is that properties near a border are more similar to each other and will be exposed to similar employment and amenity shocks over time ${ }^{16}$ For example, if foreclosures were especially high along the Atlantic coast then those cities may be more inclined to pass a VPRO, but as one moves toward the interior, properties on the western edge of the coastal city look more similar to the properties on the eastern edge of the adjacent interior city.

We expand on the baseline specification in equation (1) by adding border fixed effects, $\delta_{j(t)}$, to our existing controls. The intent of the border dummies is to absorb any time-invariant, unobserved factors that affect housing prices and are common to an adjacent VPRO/non-VPRO municipality. In our preferred specification, we interact border dummies with sale year to absorb all common location-by-time specific

\footnotetext{
${ }^{14}$ The $(t)$ subscript denotes that the fixed effect is interacted with year dummies in some specifications.

${ }^{15}$ We also experimented with clustering at the city level, but found only trivial differences in the size of the standard errors.

${ }^{16}$ Appendix Table A.2 calculates the difference in means when we limit the sample to various border distances and include a border fixed effect. Tightening the distance around the border shrinks the magnitude and, eventually, eliminates the statistical significance in the differences.
} 
variation.

To control for any level change in house prices on either side of a municipal border we include a set of difference-in-differences (DiD) dummies in VPRO and non-VPRO cities before and after the enactment of the ordinances. Specifically, we include a dummy variable for property transaction $i$ being in a city that will ever impose a VPRO, $V P R O_{i}^{\text {ever }}$, a dummy for transactions (on either side of the border) occurring after enactment of the ordinance, $V P R O_{t}^{\text {post }}$, and the interaction of the two variables, $V P R O_{i}^{\text {ever }} \times V P R O_{t}^{\text {post }}$. It is important to note that different border pairs have different enactment dates, so that there is cross-sectional variation in the timing of VPRO enactments in our sample. However, in order to keep the notation as simple as possible, we have suppressed the location subscript from $\mathrm{VPRO}_{t}^{\text {post }}$.

Our key variable of interest is the count of active foreclosures within 0.1 miles of a property at the time of sale, $F C_{i t}$. We add three foreclosure count variables to the baseline specification. This is the triple difference at the heart of the paper. The first, allows for the effect of foreclosures on sales price to vary for cities that will ever enact a VPRO; the second allows for the effect of foreclosures to be different after enactment of the ordinance for foreclosures on either side of the border; and the third allows for the effect of foreclosures to be different when the ordinance is operative in a VPRO city after enactment ${ }_{17}^{17} C_{i t}^{\frac{1}{10}} \times V P R O_{k}^{\text {ever }}$ denotes the number of nearby foreclosures that are in a jurisdiction that will ever have a VPRO, $F C_{i t}^{\frac{1}{10}} \times V P R O_{t}^{\text {post }}$ denotes the number of nearby foreclosures that occurred after the enactment of a VPRO (for both cities in the border pair), and finally, $F C_{i t}^{\frac{1}{10}} \times V P R O_{k}^{e v e r} \times V P R O_{t}^{\text {post }}$ denotes the number of nearby foreclosures subject to a VPRO city's ordinance after the enactment date. Note that we have introduced a new subscript, $k$, to denote that we are assigning VPRO status based on the location of the foreclosure, not the arms-length sale that is the unit of observation. For property sales that take place at distances greater than 0.1 miles from the VPRO/non-VPRO border, this distinction does not matter since all nearby foreclosures will be located in the same city as the reference sale. However, for sales that occur within 0.1 miles of the borders the distinction does matter, as there could be nearby foreclosures that are located on the opposite side of the border from the reference sale and we allow these externalities to spill across the border when foreclosures are in different regimes. We provide examples of our foreclosure count allocation rules before and after enactment of the ordinance for a given border pair in Figure 4

We incorporate the VPRO status dummies and our interacted foreclosures counts $\left(F C_{i t}^{\frac{1}{10}}\right)$ into the baseline

\footnotetext{
${ }^{17}$ Effectively, this is a triple difference specification, where the third source of variation, number of proximate foreclosed/vacant properties is a continuous count measure.
} 
specification introduced above. Our primary hedonic regression specification then is given by:

$$
\begin{aligned}
\ln \left(P_{i t}\right)= & \eta_{t}+\mu_{j(t)}+\delta_{j(t)}+\gamma X_{i t}+\theta_{1} F C_{i t}^{\frac{1}{10}}+\alpha_{1} V P R O_{i}^{\text {ever }}+\alpha_{2} V P R O_{t}^{\text {post }} \\
& +\alpha_{3} V P R O_{i}^{\text {ever }} \times V P R O_{t}^{\text {post }}+\theta_{2}\left(F C_{i t}^{\frac{1}{10}} \times V P R O_{k}^{\text {ever }}\right)+\theta_{3}\left(F C_{i t}^{\frac{1}{10}} \times V P R O_{t}^{\text {post }}\right) \\
& +\theta_{4}\left(F C_{i t}^{\frac{1}{10}} \times V P R O_{k}^{\text {ever }} \times V P R O_{t}^{\text {post }}\right)+\varepsilon_{i j t}
\end{aligned}
$$

We can recover the estimated net effect of nearby foreclosures on sales price by adding up the estimated $\hat{\theta}$ parameters. $\hat{\theta_{1}}$ reveals the effect of an additional foreclosure within 0.1 miles of the property sale and is the baseline foreclosure spillover estimate for all properties. However, econometrically, once we interact the foreclosure counts with VPRO and enactment status, this parameter reveals the marginal effect of foreclosure in the non-VPRO city before the date of enactment. $\hat{\theta_{1}}+\hat{\theta_{2}}$ is the estimated net effect of an additional foreclosure on average sales price in a VPRO city, but before it has enacted the ordinance. $\hat{\theta_{1}}+\hat{\theta_{3}}$ is the effect of a foreclosure on average sales price in the non-VPRO city after the adjoining city passes a VPRO. $\hat{\theta_{1}}+\hat{\theta_{2}}+\hat{\theta_{3}}$ is our best estimate of the counter-factual effect of foreclosure on sales price that would occur during the post enactment period in the VPRO city had there been no VPRO enacted. Summing the four $\hat{\theta}_{\mathrm{s}}$ yields the net effect of an additional foreclosure in an ever-VPRO city after it enacts the registration ordinance.

The parameter estimate $\hat{\theta_{4}}$ associated with the triple interaction term, $F C_{i t} \times V P R O_{k}^{\text {ever }} \times V P R O_{t}^{\text {post }}$, is our primary coefficient of interest. If VPROs mitigate the negative externalities of nearby foreclosures this term will be positive, indicating that foreclosures in this regime reduce prices by less than normal foreclosures. Formally, our null hypothesis is that the number of foreclosures in a VPRO city, after enactment of the ordinances, do not differentially affect the sales price. That is $H_{0}: \theta_{4}=0$ and our alternative hypothesis is that nearby foreclosures in cities with an operative VPRO have a smaller negative effect on transaction prices when the VPRO regime is active $\left(H_{a}: \theta_{4}>0\right.$.) We illustrate how the $\theta$ s may vary around the border in Figure 5. $\theta_{1}$ is the baseline effect of foreclosure on a conventional home sale. $\theta_{2}$ is the marginal effect of a foreclosure in a city that will at some point enact a VPRO but has not yet done so. Perhaps the externality is larger in this area because of the urban form, or some type of negative shock. $\theta_{3}$ the marginal effect of foreclosures occurring after enactment of the VPRO (for both VPRO and non-VPRO cities.) $\theta_{4}$ is the marginal effect of a foreclosure on sales price in a VPRO city after enactment of the ordinance and is thus our measure of the treatment effect of the VPRO on the foreclosure externality. 


\section{Results}

In this section we first report results from estimating the hedonic regression in equation (1) in which we test for the presence of foreclosure price spillovers in our sample of Florida properties. We then investigate the effectiveness of VPROs in ameliorating negative foreclosure externalties by estimating the triple difference specification in equation (2).

\subsection{Testing for Foreclosure Externalities in Florida}

To test for negative foreclosure price spillovers, we estimate various perturbations of equation (1), which are simplified versions of the hedonic price regressions estimated by Campbell et al. (2011). Campbell et al. (2011)'s hedonic regression (equation (2) in the paper) is different on several dimensions. First, it focuses on counts of foreclosure deeds that occurred one year before (as well as one year after) non-distressed property sales, whereas our measure is the count of properties in any stage of the foreclosure or REO process at the time of sale 18 Campbell et al. (2011) also focuses on the difference in the coefficients between foreclosures one year before and one year after the non-distressed sale 19 Another difference is that Campbell et al. (2011) focus on the difference in the number of foreclosures within a 0.1-0.25 mile ring and the number within a 0.1 mile radius ${ }^{20}$ Finally, Campbell et al. (2011) focus on a difference-weighted sum of nearby foreclosures whereas we use the unweighted sum of properties in foreclosure, which is the more common approach in the literature ${ }^{21}$ Our decision to use a much simpler hedonic specification is, in part, due to the additional complexity introduced by the VPRO variables and the interactions of the VPRO variables with nearby foreclosure counts in equation (2).

Table 3 presents the results from estimating equation (1) on the sample of property transactions that take place within 0.5 miles of a VPRO/Non-VPRO border. While this is our preferred sample, we consider alternative distances to the border below. Each column corresponds to a different specification so that we can see how sensitive the estimates are to changes in the types of fixed effects included in the regression. Column (1) presents the coefficient estimates for the effect of a proximate (within 0.1 miles) foreclosure on

\footnotetext{
${ }^{18}$ Gerardi et al. (2015) argue that the stock measure of foreclosures like the one that we use in this analysis is better than a flow measure like the Campbell et al. (2011) measure if the underlying causal mechanism is a physical/investment externality. In any event, Gerardi et al. (2015) also shows that both flow and stock measures yield similar externality estimates.

${ }^{19}$ Gerardi et al. (2015) argue that this approach is problematic if the underlying mechanism is a physical externality due to property depreciation, as foreclosures that were completed after the sale were likely in a state of disrepair well before the sale. Thus, interpreting the coefficient associated with foreclosure completions after the sale as picking up simultaneity bias is likely incorrect.

${ }^{20}$ The rationale of this approach is that foreclosure spillovers should be highly localized, so that any effects measured at a 0.1-0.25 mile difference would pick up simultaneity bias, which could then be differenced out in the regression. We estimated specifications that included foreclosure counts within a $0.1-0.25$ mile ring, but the associated coefficients were always very close to zero, and thus we decided not to include them in our regressions for the sake of simplicity.

${ }^{21}$ See the discussion on page 2,125 of Campbell et al. (2011) for a detailed description of their weights. The authors show their results are largely unchanged by using an unweighted approach.
} 
house prices controlling only for the basic property characteristics described above as well as the calendar year and quarter of the transactions. Each additional foreclosure near the reference property at the time of sale is associated with a 2.1 percent decline in the sale price. The coefficients associated with the property characteristics, vector $\hat{\gamma}$, are largely consistent with the results from a conventional hedonic estimate of home values. Larger homes with more bathrooms sell for higher prices on average. Age and lot size are not statistically different from zero, but that likely reflects the tendency of newer homes and homes with larger lots to be located further from the central business district. As soon as we control for location with census tract fixed effects (columns (2)-(6)) these variables become significant. Very small homes with only one bedroom or one bathroom are not discontinuously less valuable. Finally, we see that conditional on living area, the number of bedrooms does not predict prices.

In column (2) we add census tract fixed effects to the specification. Controlling for census tract lowers the estimated negative effect of foreclosures on sale prices by almost 40 percent as the coefficient falls from -2.1 to -1.3 percent. In columns (3)-(6) we add additional geographic and time fixed effects building up to the set of controls that we will employ in our preferred foreclosure triple difference specification. Column (3) includes county-by-year fixed effects that should absorb much of the variation in public goods and local taxes that might otherwise vary at a municipal border. In column (4) we introduce border fixed effects for properties on either side of a shared VPRO/non-VPRO border. Column (5) absorbs any remaining purely inter-temporal variation by including a vector of year-month fixed effects. Finally, in column (6) we include border-by-year fixed effects to capture any variation over time in the underlying property values near each border segment. The estimated effect of nearby foreclosures on sale prices, $\hat{\theta_{1}}$, drops slightly (in absolute magnitude) as we add controls to -0.9 percent in the most saturated specification, but remains statistically significant. This estimate is well within the range of foreclosure spillover estimates documented in the literature ${ }^{22}$

\subsection{Testing for VPRO Treatment Effects}

We now present estimation results for our principal specification of interest (equation (2)) in Table 4 in which we test if VPROs ameliorate the negative price spillovers from foreclosures. We again limit the sample to arms-length, non-foreclosure sales within 0.5 miles of a VPRO/non-VPRO border. Recall that the coefficient associated with the $F C_{i t} \times V P R O_{k}^{\text {ever }} \times V P R O_{t}^{\text {post }}$, is our parameter of interest.

Column (1) presents estimates from the triple difference specification when we only control for property characteristics and year and quarter of sale. In columns (2)-(6) of Table 4 we slowly add increasingly saturated geographic and time fixed effects, in the same manner that we did in Table 3 removing unobserved

\footnotetext{
${ }^{22}$ For an overview and summary of the literature measuring foreclosure price spillovers see Frame (2010). Our estimates in Table 3 are consistent with findings from most of the previous studies discussed in that overview, which have focused on different regions of the country and different time periods.
} 
sources of variation that might co-move with foreclosures and the VPRO treatment regime. Focusing first on the estimated differences in transaction prices across the VPRO regimes, we see that the coefficient estimate associated with sales that occur in VPRO cities before the enactment takes place ( $\hat{\alpha_{2}}$ associated with $V P R O_{i}^{\text {ever }}$ ) is not significantly different from zero. Thus, controlling for property characteristics and the exposure to foreclosures, homes in a VPRO city do not sell for less than homes in a non-VPRO city in the period before enactment. We also see, in the most saturated specification (column (6)) that homes sold in non-VPRO cities in the post enactment period do not sell for less than those sold in non-VPRO cities before enactment $\left(\hat{\alpha_{1}}=0\right)$. However, the coefficient estimate associated with sales in a VPRO city, after an enactment, $\hat{\alpha_{3}}$, is negative and significantly different from zero at the one percent level. We do not interpret this to suggest that the ordinances lowered property values. Rather, a more likely interpretation is that cities suffering from significant house price declines, perhaps precipitated by the foreclosure crisis or perhaps due to some other exogenous shock, are more likely to impose a VPRO (i.e. policy endogeneity).

Turning to the interacted foreclosure measures, we note that pooling the effects of foreclosure across cities and time as we did in Table 3 masks considerable heterogeneity in the effects of nearby foreclosures on average sale prices after the VPRO enactment. Before the ordinance was passed, foreclosures seemed to have a similar effect on average sale prices for homes on either side of the border, as $\hat{\theta_{2}}$ is small and not statistically different from zero in any of the specifications. After enactment, the effects of foreclosure on our control group in the non-VPRO city get worse as $\hat{\theta_{3}}$ is negative and statistically significant, with a magnitude -1 percent in the most saturated specification. However, this effect falls significantly in magnitude for foreclosures in an active VPRO regime as the coefficient estimate associated with the variable of interest, $F C_{i t} \times V P R O_{k}^{e v e r} \times V P R O_{t}^{\text {post }}$, is positive and staticially significant at the five percent threshold.

Moving across specifications in Table 4, we see that the inclusion of census tract fixed effects in column (2), significantly lowers the effect of nearby foreclosures overall, and lowers our estimate of the ameliorative effects of the VPRO on foreclosures as $\hat{\theta}_{4}$ falls from 3.8 percent to 1.6 percent. In column (3) we add countyyear fixed effects, which slightly reduces the estimate of $\hat{\theta}_{4}$ to 1.4 percent. Adding border fixed effects, a full slate of time dummies and border fixed effects interacted with sales year in columns (4)-(6) do not materially further reduces $\hat{\theta_{4}}$ from 1.4 percent to 1.0 percent. Using the coefficient estimates in column (6), our richest specification, we conclude that VPROs had, on average, a large, statistically significant effect in moderating the impact of foreclosures on non-distressed property transaction prices. Using the post-enactment, nonVPRO regime as the counter-factual, an active VPRO reduces the marginal effect of foreclosure on average sale prices from -1.7 percent to -0.7 percent, a reduction of more than half ${ }^{23}$

\footnotetext{
${ }^{23}$ To recover the net effect of foreclosures on house prices in an active VRPO regime for the richest specification in column (6) we take the sum: $\hat{\theta_{1}}+\hat{\theta_{2}}+\hat{\theta_{3}}+\hat{\theta_{4}}$ which equals -0.007 , less than half of the but-for estimated effect of $\hat{\theta_{1}}+\hat{\theta_{2}}+\hat{\theta_{3}}=-0.017$.
} 
The results in Table 4 show a consistent, economically important, statistically significant treatment effect of VPROs. In all specifications VPROs significantly ameliorate the negative effects of nearby foreclosures on the sales price of non-distressed properties. In our most rigorous specification (column (6)), which includes border-by-year, county-by-year, and census tract fixed effects, we find that VPROs reduce foreclosure externalities by more than 50 percent. In the balance of the paper, we conduct a series of robustness checks to ensure that these results truly reflect a causal effect of VPROs on foreclosure price spillovers.

\section{Robustness}

While the inclusion of highly disaggregated location and location-by-time fixed effects, combined with our triple difference, border-matching identification strategy is likely to address most concerns regarding simultaneity bias driving our VPRO estimates, there may still be some concerns about alternative explanations such as sample selection around the border, pre-trends in the data, or the timing of property sales. In this section, we implement various empirical exercises to try to address any remaining endogeneity concerns and show that our results are robust to alternative samples and specifications.

\subsection{Buffer Bandwidths}

The choice to construct our primary sample based on a half mile buffer on either side of a VPRO/non-VPRO border is somewhat arbitrary. There is a trade-off between sample size and buffer distance, as the closer the buffer is to the border the smaller our sample of property transactions becomes. For example, Table A.2 shows that in order to eliminate statistically significant differences in the observable property characteristics between VPRO and Non-VPRO cities, we need to restrict the sample to sales within 0.1 miles of a border. However, doing so decreases the sample size by approximately 80 percent relative to our primary sample with a buffer of 0.5 miles from a border. In addition to the large decrease in sample size, adopting too narrow of a buffer may introduce other biases as homes near the edge of cities may be unique in ways that we do not observe. For example, they may be on the edge of a police patrol zone, or further from a fire station. Cities may be tempted to place infrastructure that generates negative externalities like waste transfer or sewer treatment facilities at the outskirts of cities, which could make homes near borders more (or possibly less) susceptible to the knock-on-effect of nearby foreclosures. Since the best choice of a buffer is not completely clear, we conduct a sensitivity analysis to ensure that our VPRO results are robust to alternative choices.

Table 5 displays the results of this buffer sensitivity analysis. We estimate the exact same specification in column (6) of Table 4 but first widen, and then narrow the sample selection buffering around the VPRO/nonVPRO borders. We provide our previous results for the half mile buffer in column (3) for ease of comparison. 
Column (1) presents the coefficient estimates when we expand the sample to include sales within three miles of a border. The magnitude of $\theta_{4}$ increases to 2.4 percent at the three mile threshold, while the sum of the rest of the $\theta$ coefficients is -3.2 percent, implying that the VPRO reduces about 75 percent of the foreclosure spillover effect at the greatest distance threshold. Lowering the threshold to one mile in column (2) does not appreciably impact the estimation results. Moving from one mile down to a half mile does have a fairly sizeable impact on the estimates of $\theta_{4}$, but further lowering the distance threshold does not have much of an effect on the estimates. We begin to lose statistical significance at 0.25 miles, but the point estimates of $\theta_{4}$ do not materially change.

One nuance in our analysis that is important to note is that we assign VPRO status to foreclosed homes based on the jurisdiction of the foreclosure not the location of the sold home ${ }^{24}$ For most observations, this measure only varies with enactment of the ordinance. However, within 0.1 miles of a border (our foreclosure exposure radius) a sale could be exposed to both VPRO foreclosures and non-VPRO foreclosures as the externalities from foreclosures spill across the border. We believe that limiting the sample to within 0.1 miles of a border offers a compelling test of the foreclosure externality under both regimes. However, to isolate the sources of variation in our independent variables of interest and to better align our specification with a conventional difference-in-differences specification, we replicate our preferred specification at 0.5 miles (column (2)) but exclude homes within 0.1 miles of the border. We present the resulting estimates from this sample in column (6) of Table 5 . Our parameter of interest, $\hat{\theta_{4}}$, is marginally lower compared to its value in our preferred specification that uses all properties within one mile of a border (column (2)), but remains positive and statistically significant at the fiver percent level.

\subsection{Testing for Pre-treatment Trends}

One concern with our triple difference identification strategy is that there may be different pre-enactment trends in foreclosure price externalities in VPRO and non-VPRO cities that are driving our estimates, which have nothing to do with the ordinances themselves. To test for this we limit the sample to homes sold before the enactment of the VPRO. We then create a variable corresponding to the number of months that the sale takes place before enactment of the VPRO. Next, we interact this measure with the VPRO ever dummy, and with the interaction term between the VPRO ever and the count of nearby foreclosures, to allow for different trends in transaction prices as well as different trends in foreclosure price spillovers on each side of

\footnotetext{
${ }^{24}$ For the foreclosure interacted measures, we do not assign VPRO status based on the location of the non-distressed sale (the unit of analysis), but rather where the foreclosures is located. For example if a property is sold in the post-enactment period very close to the border on the non-VPRO side and is exposed to 3 foreclosures (within 0.1 miles) that are on the VPRO side, and 1 foreclosure on the non-VPRO side, then our total count of foreclosure variable and our interacted VPRO variables would take on the following values: \# Foreclosures $=4, F C_{i t} \times V P R O_{k}^{\text {ever }}=3, F C_{i t} \times V P R O_{t}^{\text {post }}=3, F C_{i t} \times V P R O_{k}^{\text {ever }} \times V P R O_{t}^{\text {post }}$ $=3$.
} 
a VPRO/non-VPRO border.

Table 6 displays the results. We show results for two different buffer distances: 0.5 miles and 0.25 miles. For each buffer distance we estimate two regressions, a simple specification that only includes a basic set of fixed effects (year, quarter, and tract fixed effects) and our most saturated specification that includes year-month, border-year, county-year, and tract fixed effects.

It is clear from the table that there is no evidence of differential pre-trends in foreclosure price spillovers.

The triple interaction term $\left(F C_{i t}^{\frac{1}{10}}\right.$ mile $\times V P R O_{k}^{e v e r} \times \#$ Months before VPRO $)$ is not statistically different from zero in all of the specifications. In addition, there is also no evidence of differential pre-trends in sale prices as the interaction between the VPRO ever dummy and months before VPRO enactment is statistically insignificant and close to zero in magnitude.

\subsection{Subsample Analysis and Falsification Tests}

One concern with a richly saturated model is that the underlying estimates can become sensitive to outliers. Including border-by-year fixed effects could, possibly, exacerbate this problem. In column (1) of Table 7 we present results from our primary specification but exclude all border pairs with less than 200 sales on either side of the border. The coefficient estimate of interest, $\hat{\theta}_{4}$ does not materially change.

While we tested for pre-trends in the effect of foreclosures on sale prices in Table 6, another potential concern is that the effects of foreclosures on sale prices are changing simultaneously with time and distance from the border such that when we estimate the triple difference specification at a VPRO/non-VPRO border a spurious treatment effect is generated. For example, if the foreclosure crisis is worse in the central city compared to neighborhoods near the border and the marginal effect of the crisis surges and ebbs over time but also attenuates with distance, and if the enactment of the VPRO coincided with the nadir of the foreclosure crisis, we might incorrectly ascribe the recovery in home values, and their sensitivity to foreclosures to the VPRO. In columns (2) we conduct a falsification test to see whether we obtain similar results using a false border one mile inside of a VPRO city. Finally, in column (3) we also experiment with false enactment dates, which we set to be two years before the actual dates.

Column (2) of Table 7 presents the coefficient estimates when we create a false border one mile into the VPRO jurisdiction and limit the sample to cities that eventually passed a foreclosure registration ordinance. In all other ways we replicate the specification from column (6) of Table 4 . If the effect of foreclosures on sales price was the spurious effect of a waning, but spatially attenuating, spillover effect we should obtain a similar (positive) "treatment effect" for our synthetic VPRO city. In contrast, we find that exposure to the synthetic VPRO treatment is significantly negative, so that homes exposed to foreclosure are actually more 
negatively affected, compared to homes in our "non-VPRO" control group. It is not clear what is generating this large and significant negative coefficient estimate. It could be that as we move away from the border, we're also moving closer to the epicenter of the crisis that the VPRO was meant to address. In any case, the result is not consistent with a continuous reduction in the negative effects of foreclosure as we move from the the Non-VPRO border, towards the VPRO side. Indeed, if anything, it suggests that but-for the VPRO, foreclosure effects may have been larger in those cities.

Finally, in column (3) of 7 we use the true borders but limit the analysis time to before enactment and create false enactment dates two years before the actual enactment dates. This is, in some ways, an alternative test for pre-trends. Again, if we find a positive treatment effect for foreclosures subject to an "active" VPRO in this exercise it would suggest that the enactment of the VPRO simply coincided with a steady reduction in the marginal harm of a foreclosure in a VPRO city relative to a non-VPRO city. However, our estimate of $\hat{\theta_{4}}$ is not statistically different from zero nor economically meaningful. Foreclosures that occur when our synthetic ordinance is active have the same negative effects as foreclosures before the law or outside the border.

\subsection{Redefining Nearby Foreclosures}

There is a potential measurement issue regarding the exact timing of the VPRO treatment that we will attempt to address in this section. In Panel A of Table 1 we see that some of the VPROs in our sample are triggered by default, while some are triggered by vacancy. Furthermore, more than half of the VPROs must be triggered by both vacancy and default (48 out of 83). While we have information about the default status of each property in our dataset, we do not have information about the vacancy status of each property. Since we have, thus far, defined a nearby foreclosure to be any nearby property that is either in the foreclosure process due to the borrower defaulting (i.e. a property with an associated lis penden filing) or that has completed the foreclosure process and is in the state of REO and owned by the lender, we may be misassigning VPRO treatment to properties that are in the foreclosure process, but that are still occupied 25

In order to address this issue, we change our nearby foreclosure definition to only include properties that have completed the foreclosure process and are REO. We then re-estimate our primary regression specification using this alternative definition of nearby foreclosure. Since REO properties, which are being sold by the lender, are always vacant, this should directly address the measurement issue.

\footnotetext{
${ }^{25} \mathrm{~A}$ priori, it is not completely clear that this is a significant issue. Based on a careful inspection of the ordinances themselves, in virtually all cases where both a default and a vacancy are required to trigger the VPRO, a default triggers a monitoring requirement by the lender. Specifically, the lender is required to periodically (typically every week) inspect the property to determine if it is vacant or occupied. This monitoring requirement alone may be enough to trigger increased maintenance and oversight of properties in the foreclosure process. In other words, because of the monitoring requirements, even in cases where a default does not technically trigger the VPRO, it may effectively trigger it.
} 
Table 8 displays the results of this exercise. Panel A displays results from specifications that correspond exactly to those in Table 4 where we condition on a relatively simple set of covariates in column (1) and then build up the specification to our most saturated model in column (6). In Panel B, we estimate our most saturated model and change the distance thresholds from the border in the exact same manner as we did in Table $55^{26}$ Compared to Tables 4 and 5 the results are qualitatively very similar. For the most saturated specification in column (6) of Panel A, we see that $\theta_{2}$ is not statistically different from zero, implying that before VPRO enactment the foreclosure spillover effect was approximately the same on each side of the border. In addition, $\theta_{3}$ is again negative and statistically significant, which implies that the spillover effect of nearby foreclosed properties on sale prices in the non-VPRO city after enactment gets worse. Finally, we see that $\theta_{4}$ is again positive and statistically significant, which shows that the VPRO enactment mitigated foreclosure spillovers.

While the qualitative results do not change, the coefficient estimates are all significantly larger in absolute magnitude compared to their counterparts in Tables 4 and 5 . This suggests that there are significantly larger negative spillover effects for REO properties, in general. Comparing the estimates in column (6) between Tables 4 and 8 , the foreclosure spillover effects on the VPRO side of the border before enactment $\left(\theta_{1}+\theta_{2}\right)$ are more than twice as large ( $-2 \%$ versus $-0.8 \%)$, when only REO properties are considered in the nearby foreclosure definition. The spillover effect on the non-VPRO side of the border after enactment $\left(\theta_{1}+\theta_{2}+\theta_{3}\right)$ is also significantly larger $(-4.8 \%$ versus $-1.9 \%)$. Despite the larger negative spillovers, our estimate of the VPRO treatment effect is positive and statistically significant, and is quantitatively important. The point estimate of $4.5 \%$ for $\theta_{4}$ implies that the VPRO virtually eliminates the entire negative foreclosure externality, as the marginal effect of foreclosure on average sale prices declines from $-4.8 \%$ to $-0.3 \%$.

\section{$7 \quad$ Foreclosure Price Effects}

In this section we test for whether the introduction of VPROs had a direct impact on the transaction prices of foreclosed properties. We view this as an interesting question in its own right, but also as a consistency check on the interpretation of our estimation results. If the VPROs ameliorate negative foreclosure price spillovers by increasing the amount of investment in property maintenance and upkeep, then we should expect to see positive effects on the values of the foreclosed properties themselves. Thus, we add REO sales to our sample of property transactions (i.e. transactions between mortgage lenders and arms-length homebuyers), and estimate the following triple-difference model:

\footnotetext{
${ }^{26}$ Note, all specifications in Table 8 condition on the same set of property characteristics that we have included in all of the regressions reported thus far. To conserve space, we do not report their coefficient estimates in the table.
} 


$$
\begin{aligned}
\ln \left(P_{i t}\right)= & \eta_{t}+\mu_{j(t)}+\delta_{j(t)}+\gamma X_{i t}+\beta_{1} R E O_{i t}^{\text {sale }} \\
& +\alpha_{1} V P R O_{i}^{\text {ever }} \alpha_{2}+V P R O_{t}^{\text {post }}+\alpha_{3}\left(V P R O_{t}^{\text {post }} \times V P R O_{i}^{\text {ever }}\right) \\
& +\beta_{2} R E O_{i t}^{\text {sale }} \times V P R O_{i}^{\text {ever }}+\beta_{3}\left(R E O_{i t}^{\text {sale }} \times V P R O_{t}^{\text {post }}\right) \\
& +\beta_{4}\left(R E O_{i t}^{\text {sale }} \times V P R O_{i}^{\text {ever }} \times V P R O_{t}^{\text {post }}\right)+\varepsilon_{i j t}
\end{aligned}
$$

where $R E O_{i t}^{\text {sale }}$ is a dummy variable that distinguishes between non-distressed and REO transactions. Our focus is on the coefficient associated with the triple interaction term, $\beta_{4}$, which we interpret as the treatment effect of VPROs on the average sale price of REO properties. The triple difference specification, where we compare REO versus non-distressed transactions, before versus after VPRO enactment in VPRO versus non-VPRO cities, controls for any level change in prices between VPRO and non-VPRO cities. If there is some unobserved shock that lowers home values in the VPRO cities, like for example, a new disamenity or an adverse municipal budget shock that pushes up taxes or lowers services, that should affect all homes in the VPRO city ${ }^{27}$ The triple difference specification is crucial to controlling for this, as it allows us to compare how the REO sales prices responded to the VPRO treatment relative to the non-distressed prices.

Table 9 displays the estimation results, where each column corresponds to a different distance threshold from the border. The first notable result in the table is that we find an economically large foreclosure discount. The base discount, $\beta_{1}$, which corresponds to the average difference in transaction prices between REO and non-distressed properties in non-VPRO cities before enactment is between $21 \%$ and $26 \%$. These differences are consistent with other estimates of foreclosure discounts in the literature (e.g. Campbell et al. 2011). Turning to our coefficient of interest, $\beta_{4}$, depending on the sample, our estimate of the effect of VPROs on REO sale prices ranges from $4.6 \%-11.4 \%$. Thus, we find evidence that VPROs do indeed significantly increase the values of foreclosed properties.

\section{Conclusion}

Governments at all levels struggled to respond to the mortgage foreclosure crisis of the mid-to-late 2000s. Many local governments, including a large number of Florida cities, passed Vacant Property Registration Ordinances to improve the monitoring and maintenance of distressed homes. In this paper we merge a novel dataset of VPRO enactments with foreclosure and property transactions data to investigate the extent to which VPROs mitigate foreclosure externalities. We first document the existence of foreclosure price spillovers in Florida using a standard hedonic regression framework. We find magnitudes that are consistent

\footnotetext{
${ }^{27}$ For example, according to the results reported in column (6) of Table 4 prices of non-distressed sales were almost $8 \%$ lower in VPRO cities compared to non-VPRO cities after enactment. In section 5 we interpreted this result to be consistent with policy endogeneity, whereby the cities suffering worse house price declines were more likely to implement a VPRO.
} 
with estimates of previous studies in the literature that have focused on different regions and different time periods. We then match property transactions in cities that enacted VPROs to sales in bordering municipalities that did not enact VPROs (non-VPRO areas). Using a triple difference identification strategy, and focusing on a sample of properties close to the VPRO/non-VPRO borders, we find that VPROs significantly ameliorate the negative effect of foreclosure on prices, compared to adjoining cities that did not impose ordinances.

Florida was one of the epicenters of the housing boom and bust. It experienced one of the greatest run-ups in housing prices before the crash. It is also a judicial foreclosure state and as a result experienced lengthy foreclosure timelines during the crisis leaving large numbers of vacant and neglected homes for extended periods of time. Thus, our estimates of the foreclosure externality and the ameliorative effects of VPROs may be an upper bound. On the other hand, the decision by cities to pass VPROs was not random. Cities that passed VPROs were plagued by more foreclosures ex-ante and were somewhat denser and older, and thus, perhaps more likely to suffer negative externalities. Despite our carefully limited sample and rich set of controls, homes in VPRO cities may still be unobservably more susceptible to foreclosure, and thus our estimate of the VPRO treatment effect may be biased downward due to policy endogeneity.

Finally, beyond program evaluation, this paper informs our understanding of the true nature of the foreclosure externality. VPROs are explicitly intended to prevent excessive depreciation of foreclosed properties. Our estimates of a positive and quantitatively important ameliorative effect of VPROs on foreclosure price spillovers suggests that foreclosures lower neighboring property values through a non-pecuniary, physical externality.

Given that VPROs had relatively little enforcement cost, indeed they raised revenue for the city, they seem a relatively efficacious way to directly address the foreclosure externalities arising from any future downturn in housing markets. Certainly compared to other interventions like the Home Affordable Modification Program (HAMP) that attempted to forestall bank initiated foreclosures (and their spillovers) via costly inducements to banks, VPROs appear to be highly cost effective. 


\section{References}

Anenberg, E. and E. Kung (2014). Estimates of the size and source of price declines due to nearby foreclosures. American Economic Review 104(8), 2527-2551.

Biswas, A. (2012). Housing submarkets and the impacts of foreclosures on property prices. Journal of Housing Economics 21(3), 235 - 245.

Campbell, J. Y., S. Giglio, and P. Pathak (2011). Forced sales and house prices. American Economic Review $101(5), 2108-2131$.

Cordell, L., L. Geng, L. S. Goodman, and L. Yang (2015). The cost of foreclosure delay. Real Estate Economics 43(4), 916-956.

Fisher, L. M., L. Lambie-Hanson, and P. Willen (2015). The role of proximity in foreclosure externalities: Evidence from condominiums. American Economic Journal: Economic Policy 7(1), 119-40.

Frame, W. S. (2010). Estimating the effect of mortgage foreclosures on nearby property values: A critical review of the literature. Economic review 95.

Gerardi, K., L. Lambie-Hanson, and P. S. Willen (2013). Do borrower rights improve borrower outcomes? evidence from the foreclosure process. Journal of Urban Economics 73(1), 1-17.

Gerardi, K., E. Rosenblatt, P. S. Willen, and V. Yao (2015). Foreclosure externalities: New evidence. Journal of Urban Economics 87, $42-56$.

Harding, J. P., E. Rosenblatt, and V. W. Yao (2008, July). The contagion effect of foreclosed properties. The Journal of Urban Economics 66(3), 164-178.

Harding, J. P., S. S. Rosenthal, and C. Sirmans (2007). Depreciation of housing capital, maintenance, and house price inflation: Estimates from a repeat sales model. Journal of Urban Economics 61(2), 193-217.

Immergluck, D. and G. Smith (2006). The external costs of foreclosure: The impact of single-family mortgage foreclosures on property values. Housing Policy Debate 17(1), 57-79.

Lee, Y. S., P. Terranova, and D. Immergluck (2013). New data on local vacant property registration ordinances. Cityscape: A Journal of Policy Development and Research 15(2), 259 - 266.

Lin, Z., E. Rosenblatt, and V. Yao (2009). Spillover effects of foreclosures on neighborhood property values. The Journal of Real Estate Finance and Economics 38(4), 387-407. 
Rao, J. and G. Walsh (2009). Foreclosing a dream: State laws deprive homeowners of basic protections. National Consumer Law Center.

Rogers, W. H. and W. Winter (2009). The impact of foreclosures on neighboring housing sales. The Journal of Real Estate Research 31(4), 455-480.

Schuetz, J., V. Been, and I. Ellen (2008). Neighborhood effects of concentrated mortgage foreclosures. Journal of Housing Economics 17(4), 306-319. 
Figure 1: Florida Cities with a Vacant Property Registration Ordinance

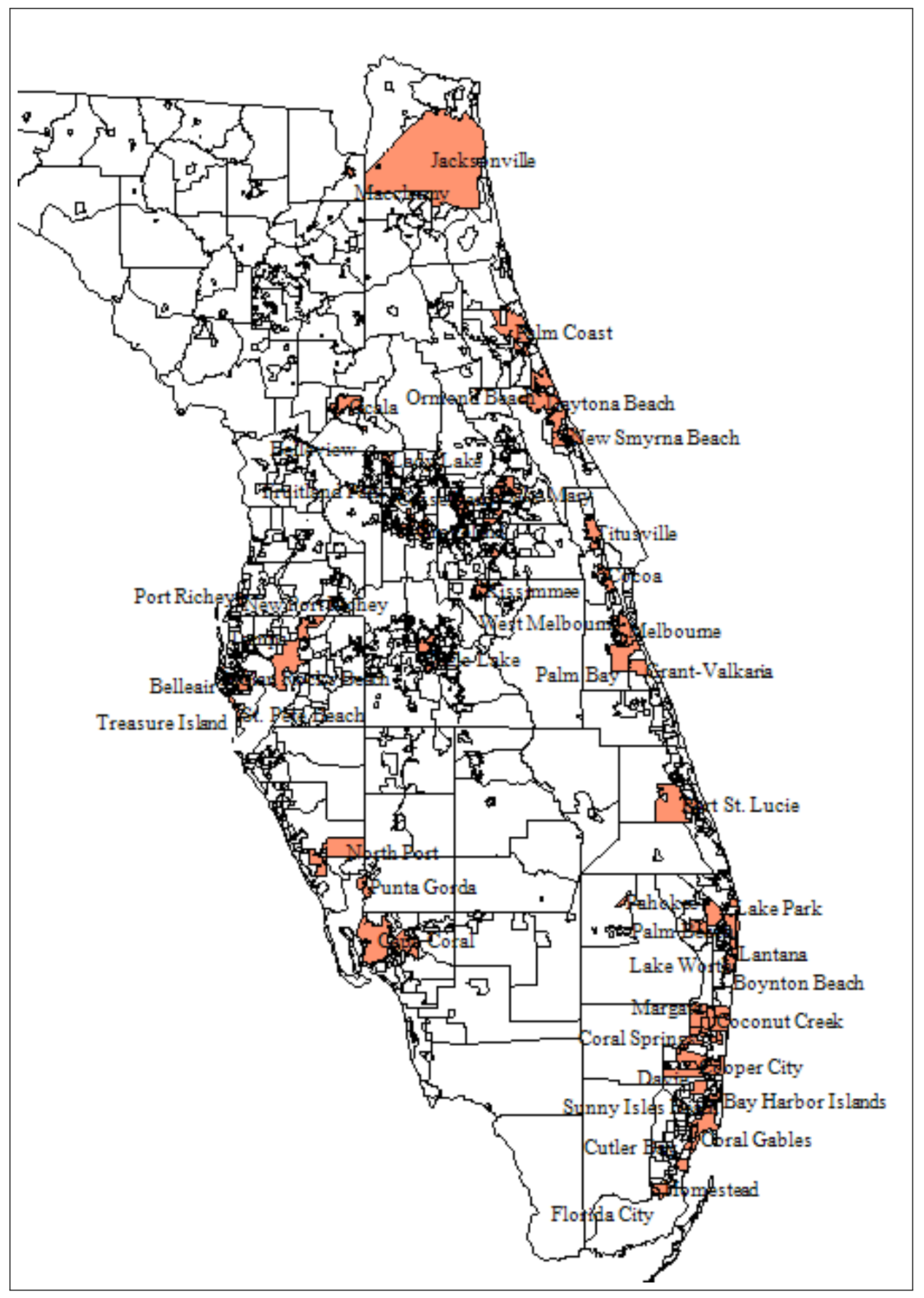

Notes: This figure displays the Florida cities that enacted a VPRO through April 2012. A detailed list of all cities and those used in the estimation sample can be found in Table A.1 Note that there were no VPROs in the panhandle. 
Figure 2: Example of Border Pairings

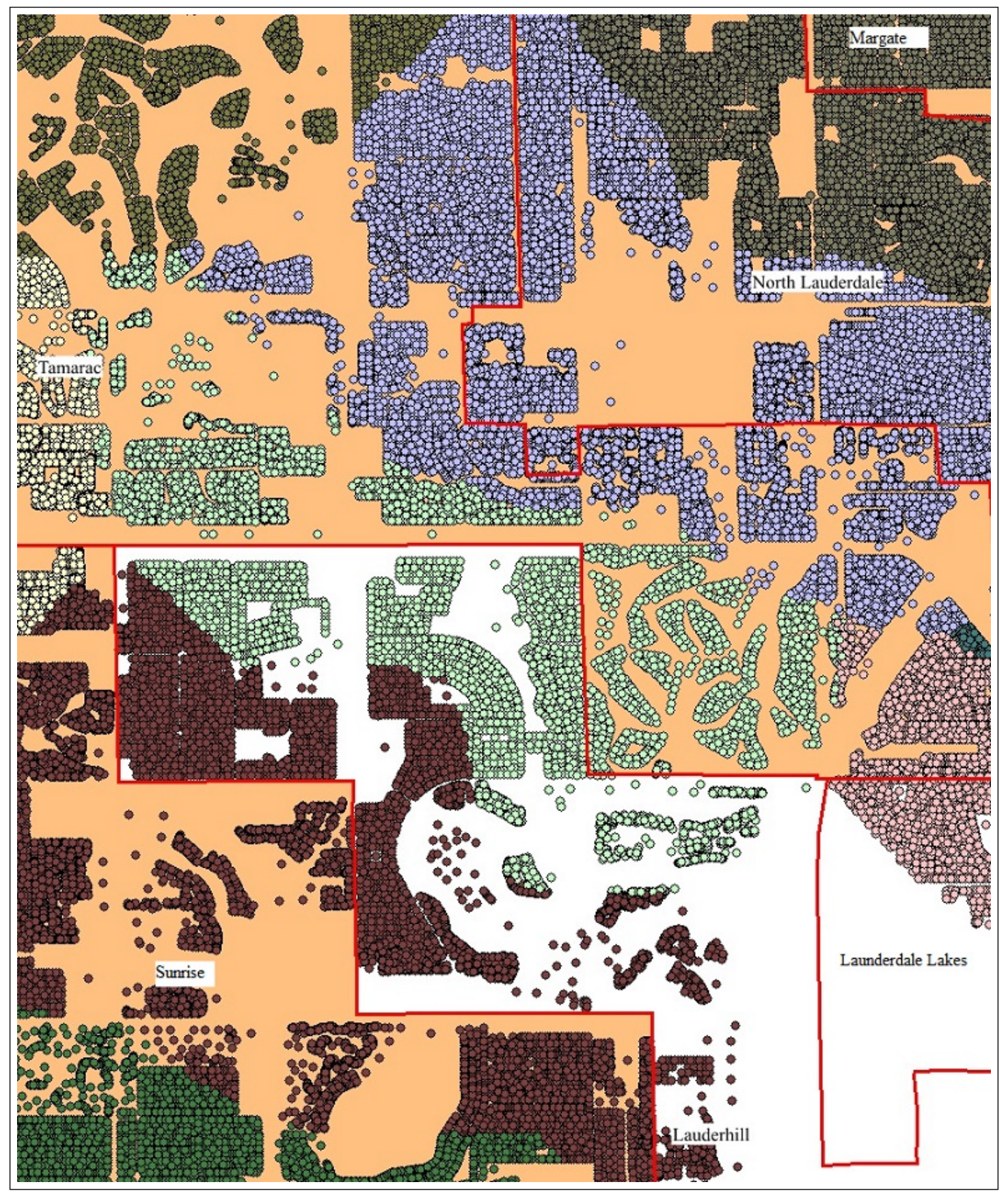

Notes: This figure illustrates the border discontinuity design implemented in the empirical analysis. Municipal boundaries are denoted by the red/thick line. Homes are colored/shaded by their common border ID, that matches homes to the nearest municipal border. We do not use all border pairs, only those that straddle a VPRO (shaded) and non-VPRO border. We also exclude borders with unincorporated county land. So, in this example only the Sunrise/Lauderhill (burgundy), Tamarac/Lauderhill (green), and the Tamarac/Launderdale Lakes borders (pink) border pairs are used. 
Figure 3: Counting Nearby Foreclosures Based on VPRO Status

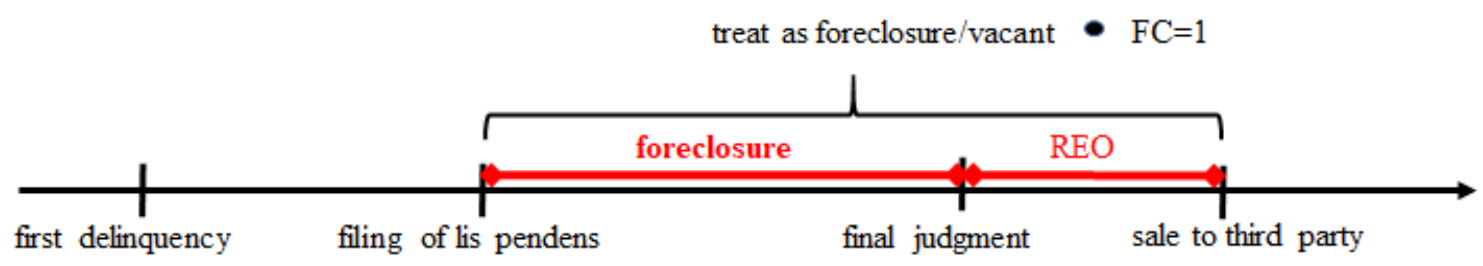

Note: This figure illustrates when a property is treated as being foreclosed and/or vacant for our analysis.

Figure 4: Counting Nearby Foreclosures Based on VPRO Status
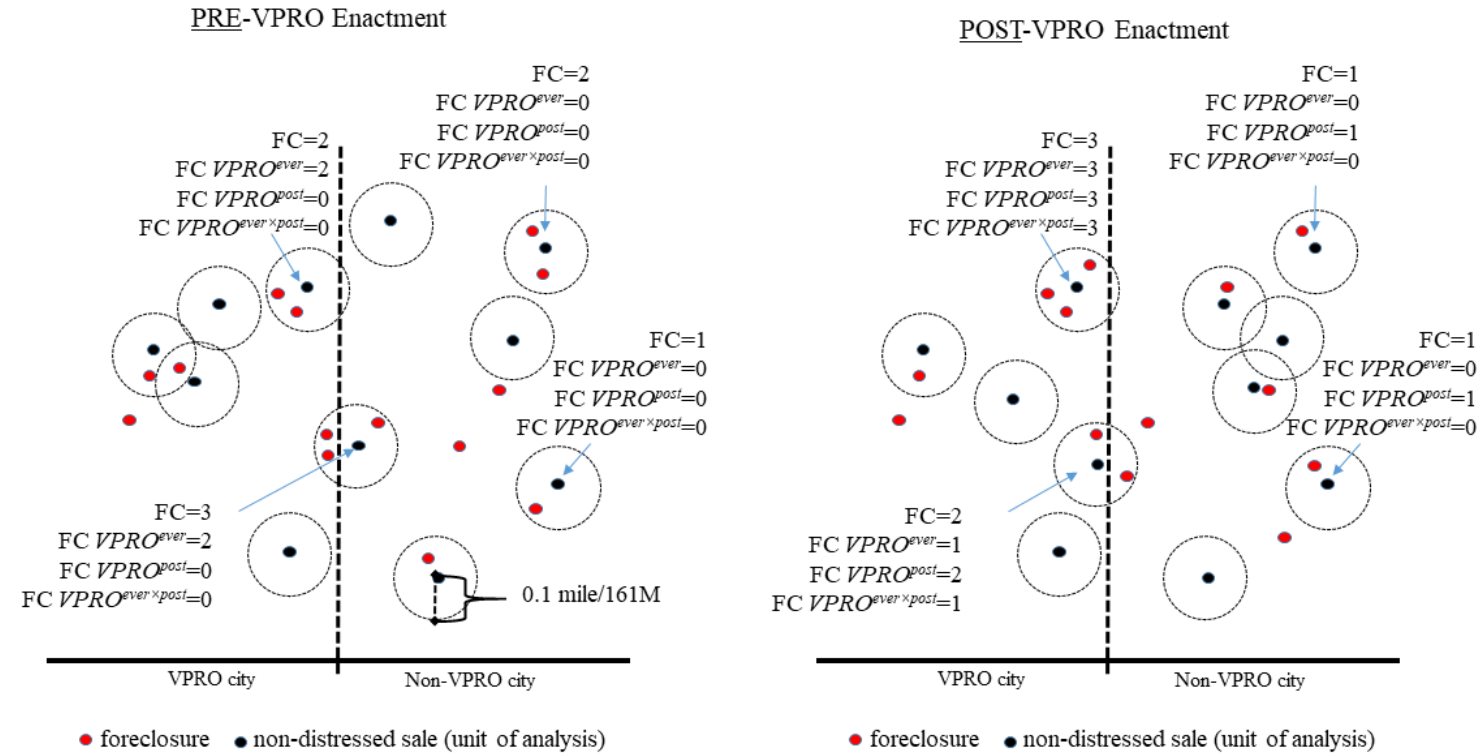

Note: this figure illustrates how we count nearby foreclosure based on the Vacant Property Registration Ordinance (VPRO) status. The figure on the left shows how we count foreclosures (red) near non-distressed sales (blue) before the enactment of a VPRO for that border pair. The figure on the right illustrates how we count nearby foreclosure after enactment of a VPRO for that border pair. 
Figure 5: Interacted Foreclosure Externality Coefficients at Municipal Borders

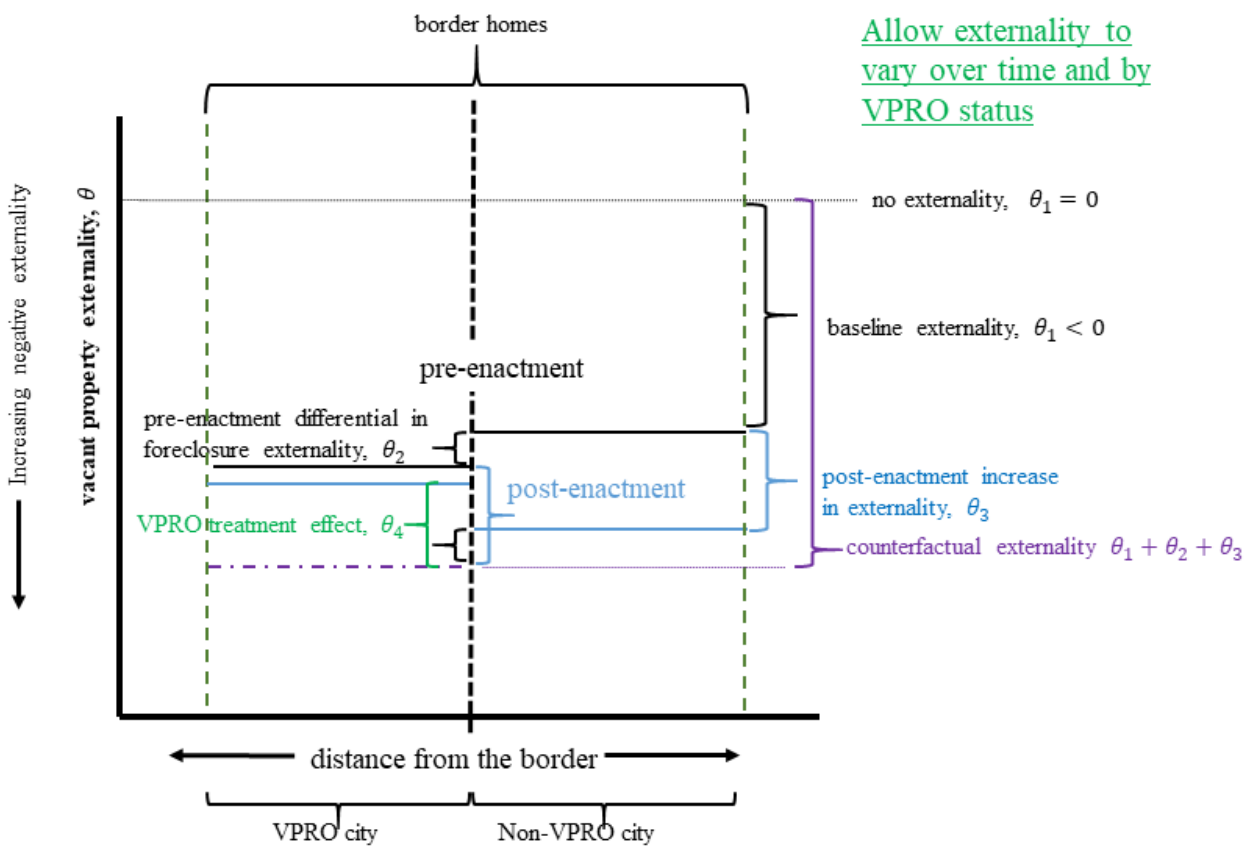

Note: This figure illustrates how the externality from foreclosure is allowed to vary on either side of a municipal border before and after enactment of the VPRO. $\left.\theta_{[} 1\right]$ is the baseline effect of foreclosure on a conventional home sale. $\left.\theta_{[} 2\right]$ is the marginal effect of a foreclosure in a city that will at some point enact a VPRO. $\left.\theta_{[} 3\right]$ the marginal effect of foreclosures occuring after enactment of the VPRO (for both VPRO and non-VPRO cities. $\theta_{[4]}$ is the marginal effect of a foreclosure on sales price in a VPRO city after enactment of the ordinance. The coefficient estimate, $\left.\hat{\theta_{[}} \hat{4}\right]$, is our measure of the treatment effect of the VPRO on the foreclosure externality. 
Table 1: VPRO Enactment Dates and Characteristics

Panel A: \# VPROs Enacted in Florida

\begin{tabular}{cccccc}
\hline & & \multicolumn{5}{c}{ Fraction triggered by: } \\
\cline { 3 - 6 } Enactment Year & Count & $\begin{array}{c}\text { Vacancy } \\
\text { Only }\end{array}$ & $\begin{array}{c}\text { Default } \\
\text { Only }\end{array}$ & Vacancy \& Default & Vacancy or Default \\
\hline 2008 & 13 & 0 & 2 & 9 & 4 \\
2009 & 28 & 0 & 11 & 16 & 12 \\
2010 & 28 & 1 & 6 & 16 & 6 \\
2011 & 13 & 0 & 6 & 7 & 1 \\
2012 & 1 & 0 & 1 & 0 & 35 \\
\hline Total & 83 & 1 & 26 & 48 & \\
\hline
\end{tabular}

Panel B: Descriptive Statistics of VPRO Reporting and Compliance Requirements

\begin{tabular}{|c|c|c|c|c|c|}
\hline Variable & Count & Mean & Std. Dev. & Min & Max \\
\hline \multicolumn{6}{|l|}{ Fine schedule for not registering: } \\
\hline$<=\$ 250$ & 15 & & & & \\
\hline$\$ 250>,<=\$ 500$ & 43 & & & & \\
\hline$\$ 500>$ & 3 & & & & \\
\hline Not specified & 22 & & & & \\
\hline Lien on property & 18 & & & & \\
\hline Failure to register a crime/misdemeanor & 18 & & & & \\
\hline \# Security measures & & 2.71 & 0.81 & 0 & 4 \\
\hline \multicolumn{6}{|l|}{ \# Required to: } \\
\hline Post contact sign & 57 & & & & \\
\hline Local property manager & 18 & & & & \\
\hline \multicolumn{6}{|l|}{ Inspection frequency: } \\
\hline Weekly & 21 & & & & \\
\hline Bi-weekly & 30 & & & & \\
\hline Monthly or more & 17 & & & & \\
\hline No inspection & 15 & & & & \\
\hline \# Maintenance items & & 4.7 & 1.43 & 2 & 8 \\
\hline \multicolumn{6}{|l|}{ Examples: } \\
\hline No furniture/debris in yard & 67 & & & & \\
\hline No graffiti & 78 & & & & \\
\hline Maintain landscaping and plants & 66 & & & & \\
\hline Maintain pools and spas & 82 & & & & \\
\hline
\end{tabular}

Notes: Panel A displays the count of VPRO enactments by year in the state of Florida and also breaks the VPROs down by the type of trigger mechanism. Data on VPROs runs through April 2012. The top five largest cities (by number of ZIP codes) that have enacted VPROs in FL are Miami (2008), Tampa (2009), Pinellas Park (2009), Fort Myers (2010), and Jacksonville (2010). Panel B shows various descriptive statistics on the stringency of the VPROs including information on fines for not registering, the frequency of inspections by local officials, requirements for securing properties, and requirements for routine maintenance. 


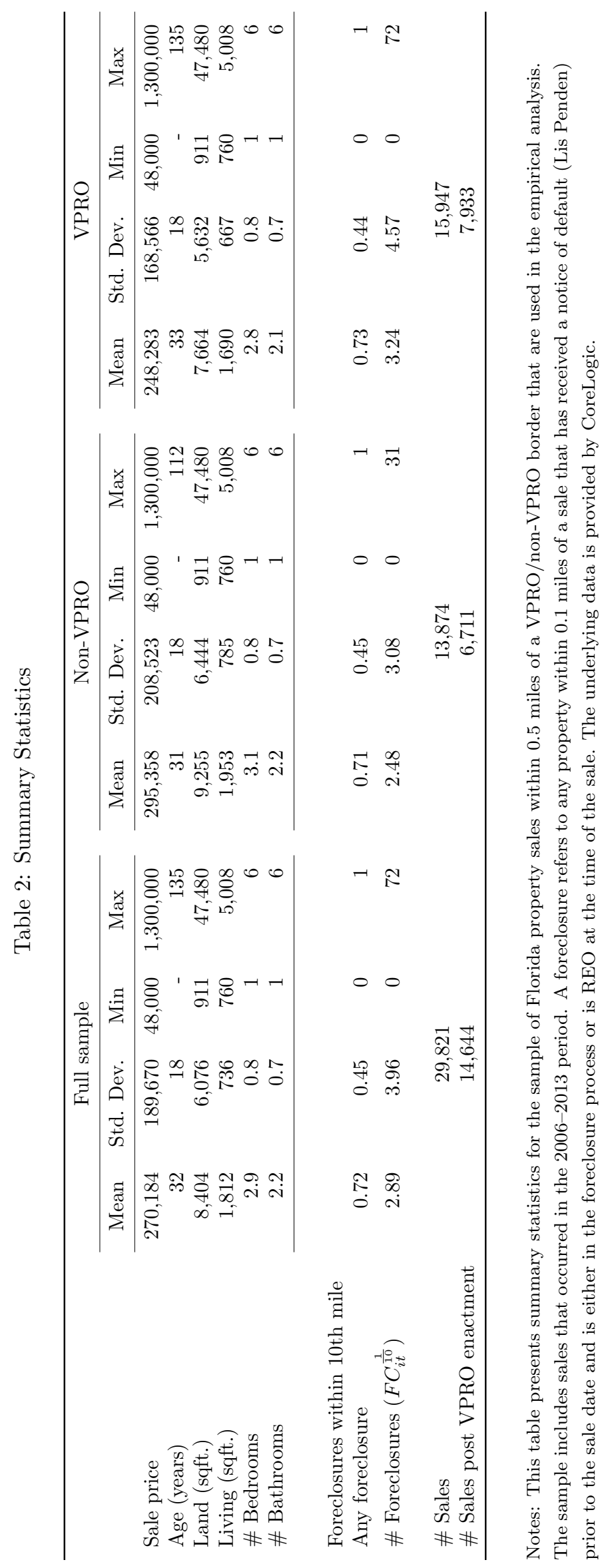


Table 3: Estimates of Foreclosure Spillovers

\begin{tabular}{|c|c|c|c|c|c|c|}
\hline \multirow{3}{*}{ Distance to Border: } & \multicolumn{6}{|c|}{ Dependent Variable: Ln(Sale Price) } \\
\hline & \multicolumn{6}{|c|}{$<\frac{1}{2}$ Mile } \\
\hline & (1) & $(2)$ & $(3)$ & (4) & (5) & (6) \\
\hline$F C_{i t}^{\frac{1}{10}}(\#$ foreclosures $)(\hat{\theta})$ & $\begin{array}{c}-0.021^{* *} \\
(-2.24)\end{array}$ & $\begin{array}{c}-0.013^{* * *} \\
(-3.43)\end{array}$ & $\begin{array}{c}-0.012^{* * *} \\
(-3.29)\end{array}$ & $\begin{array}{c}-0.012^{* * *} \\
(-3.24)\end{array}$ & $\begin{array}{c}-0.011^{* * *} \\
(-3.13)\end{array}$ & $\begin{array}{c}-0.009^{* * *} \\
(-2.83)\end{array}$ \\
\hline Ln(land sqft.) & $\begin{array}{l}0.059 \\
(1.39)\end{array}$ & $\begin{array}{c}0.205^{* * *} \\
(14.73)\end{array}$ & $\begin{array}{c}0.206^{* * *} \\
(14.35)\end{array}$ & $\begin{array}{c}0.207^{* * *} \\
(14.20)\end{array}$ & $\begin{array}{c}0.207^{* * *} \\
(14.14)\end{array}$ & $\begin{array}{c}0.212^{* * *} \\
(15.06)\end{array}$ \\
\hline Ln(living sqft.) & $\begin{array}{c}1.031^{* * *} \\
(12.03)\end{array}$ & $\begin{array}{c}0.541^{* * *} \\
(20.98)\end{array}$ & $\begin{array}{c}0.542^{* * *} \\
(21.21)\end{array}$ & $\begin{array}{c}0.533^{* * *} \\
(22.09)\end{array}$ & $\begin{array}{c}0.536^{* * *} \\
(22.59)\end{array}$ & $\begin{array}{c}0.537^{* * *} \\
(21.85)\end{array}$ \\
\hline \# Bedrooms & $\begin{array}{l}-0.018 \\
(-0.73)\end{array}$ & $\begin{array}{c}-0.015^{*} \\
(-1.85)\end{array}$ & $\begin{array}{c}-0.015^{*} \\
(-1.88)\end{array}$ & $\begin{array}{c}-0.013^{*} \\
(-1.71)\end{array}$ & $\begin{array}{c}-0.014^{*} \\
(-1.81)\end{array}$ & $\begin{array}{c}-0.013^{*} \\
(-1.71)\end{array}$ \\
\hline \# Bathrooms & $\begin{array}{c}0.100^{* * *} \\
\quad(5.10)\end{array}$ & $\begin{array}{c}0.067^{* * *} \\
\quad(6.69)\end{array}$ & $\begin{array}{c}0.068^{* * *} \\
(6.94)\end{array}$ & $\begin{array}{l}0.066^{* * *} \\
\quad(6.70)\end{array}$ & $\begin{array}{c}0.067^{* * *} \\
(6.81)\end{array}$ & $\begin{array}{c}0.065^{* * *} \\
\quad(6.52)\end{array}$ \\
\hline Age & $\begin{array}{l}-0.010 \\
(-0.83)\end{array}$ & $\begin{array}{c}-0.020^{* * * *} \\
(-3.94)\end{array}$ & $\begin{array}{c}-0.020^{* * *} \\
(-3.65)\end{array}$ & $\begin{array}{c}-0.019 * * * \\
(-3.46)\end{array}$ & $\begin{array}{c}-0.019^{* * * *} \\
(-3.39)\end{array}$ & $\begin{array}{c}-0.019 * * * \\
(-3.78)\end{array}$ \\
\hline $\mathrm{Age}^{2}$ & $\begin{array}{l}0.000 \\
(0.46) \\
\end{array}$ & $\begin{array}{c}0.000^{* *} \\
(2.37)\end{array}$ & $\begin{array}{c}0.000^{* *} \\
(2.29)\end{array}$ & $\begin{array}{c}0.000^{* *} \\
(2.08)\end{array}$ & $\begin{array}{c}0.000^{* *} \\
(2.05)\end{array}$ & $\begin{array}{c}0.000^{* *} \\
(2.08)\end{array}$ \\
\hline $\begin{array}{l}\text { Sale qtr. F.E. } \\
\text { Sale year F.E. }\end{array}$ & $\begin{array}{l}\mathrm{x} \\
\mathrm{x}\end{array}$ & $\begin{array}{l}\mathrm{x} \\
\mathrm{x}\end{array}$ & $\mathrm{x}$ & $\mathrm{x}$ & & \\
\hline Sale year-month F.E. & & & & & $\mathrm{x}$ & $\mathrm{x}$ \\
\hline $\begin{array}{l}\text { Border F.E. } \\
\text { Border-by-year F.E. }\end{array}$ & & & & $\mathrm{x}$ & $\mathrm{x}$ & $\mathrm{x}$ \\
\hline $\begin{array}{l}\text { County-by-sale year F.E. } \\
\text { Census tract F.E. }\end{array}$ & & $\mathrm{x}$ & $\begin{array}{l}\mathrm{x} \\
\mathrm{x}\end{array}$ & $\begin{array}{l}\mathrm{x} \\
\mathrm{x}\end{array}$ & $\begin{array}{l}\mathrm{x} \\
\mathrm{x}\end{array}$ & $\begin{array}{l}\mathrm{x} \\
\mathrm{x}\end{array}$ \\
\hline $\begin{array}{l}\# \text { Observations } \\
R^{2}\end{array}$ & $\begin{array}{c}29,821 \\
0.60\end{array}$ & $\begin{array}{c}29,817 \\
0.81\end{array}$ & $\begin{array}{c}29816 \\
0.82\end{array}$ & $\begin{array}{c}29,816 \\
0.81\end{array}$ & $\begin{array}{c}29,816 \\
0.82\end{array}$ & $\begin{array}{c}29,806 \\
0.83\end{array}$ \\
\hline
\end{tabular}

Notes: All specifications also include dummies for homes with only one bedroom, only one bathroom, missing values, a constant and structure age as a quartic. Sales in the sample are limited to arms-length transactions of single-family homes with 6 or fewer beds and baths in incorporated areas of sufficient population density as described in section 3. Sale prices are trimmed at the 1st and 98th percentiles, and square footages are winsorized at the 1st and 99th percentiles. Borders are limited to pairs of jurisdictions in which one enacts a VPRO and the other does not. Errors are clustered by city. T-statistic are in parentheses. $*, * *,{ }^{* * *}$ denote significantly different from zero at the 10,5 , and 1 percent level of significance imposing a two-tail test. The underlying data is provided by CoreLogic. 
Table 4: The Effect of VPRO Enactments on Foreclosure Spillovers

\begin{tabular}{|c|c|c|c|c|c|c|}
\hline \multirow{3}{*}{ Distance to Border: } & \multicolumn{6}{|c|}{ Dependent Variable: Ln(Sale Price) } \\
\hline & \multicolumn{6}{|c|}{$<\frac{1}{2}$ Mile } \\
\hline & $(1)$ & $(2)$ & $(3)$ & $(4)$ & $(5)$ & $(6)$ \\
\hline$F C_{i t}^{\frac{1}{10} m i l e}(\#$ Foreclosures $)\left(\hat{\theta_{1}}\right)$ & $\begin{array}{c}-0.020^{* * *} \\
(-2.94)\end{array}$ & $\begin{array}{c}-0.009 * * * \\
(-3.91)\end{array}$ & $\begin{array}{c}-0.008^{* * *} \\
(-3.40)\end{array}$ & $\begin{array}{c}-0.008^{* * *} \\
(-3.14)\end{array}$ & $\begin{array}{c}-0.006^{* *} \\
(-2.15)\end{array}$ & $\begin{array}{c}-0.007^{* *} \\
(-2.25)\end{array}$ \\
\hline $\operatorname{VPRO}_{i}^{\text {ever }}(d)$ & $\begin{array}{c}0.048^{*} \\
(1.68)\end{array}$ & $\begin{array}{l}0.013 \\
(0.60)\end{array}$ & $\begin{array}{l}0.014 \\
(0.63)\end{array}$ & $\begin{array}{l}0.005 \\
(0.26)\end{array}$ & $\begin{array}{l}0.008 \\
(0.37)\end{array}$ & $\begin{array}{l}0.004 \\
(0.17)\end{array}$ \\
\hline $\operatorname{VPRO}_{t}^{\text {post }}(d)$ & $\begin{array}{l}0.096 \\
(1.39)\end{array}$ & $\begin{array}{c}0.038^{*} \\
(1.84)\end{array}$ & $\begin{array}{l}0.029 \\
(1.39)\end{array}$ & $\begin{array}{l}0.026 \\
(1.26)\end{array}$ & $\begin{array}{l}0.038^{*} \\
(1.76)\end{array}$ & $\begin{array}{l}0.013 \\
(0.76)\end{array}$ \\
\hline $\mathrm{VPRO}_{i}^{\text {ever }} \times V P R O_{t}^{\text {post }}(d)$ & $\begin{array}{c}-0.200^{* * *} \\
(-4.45)\end{array}$ & $\begin{array}{c}-0.104^{* * *} \\
(-3.33)\end{array}$ & $\begin{array}{c}-0.099 * * * \\
(-3.48)\end{array}$ & $\begin{array}{c}-0.098^{* * *} \\
(-3.41)\end{array}$ & $\begin{array}{c}-0.096^{* * *} \\
(-3.37)\end{array}$ & $\begin{array}{c}-0.085^{* * *} \\
(-2.88)\end{array}$ \\
\hline$F C_{i t}^{\frac{1}{10} m i l e} \times V P R O_{k}^{\text {ever }}\left(\hat{\theta_{2}}\right)$ & $\begin{array}{l}-0.002 \\
(-0.31)\end{array}$ & $\begin{array}{l}-0.003 \\
(-1.26)\end{array}$ & $\begin{array}{l}-0.002 \\
(-0.78)\end{array}$ & $\begin{array}{l}-0.002 \\
(-0.97)\end{array}$ & $\begin{array}{l}-0.002 \\
(-0.90)\end{array}$ & $\begin{array}{l}-0.000 \\
(-0.10)\end{array}$ \\
\hline$F C_{i t}^{\frac{1}{10} m i l e} \times V P R O_{t}^{p o s t}\left(\hat{\theta_{3}}\right)$ & $\begin{array}{c}-0.029 * * * \\
(-4.51)\end{array}$ & $\begin{array}{c}-0.015^{* * *} \\
(-3.94)\end{array}$ & $\begin{array}{c}-0.014^{* * *} \\
(-3.86)\end{array}$ & $\begin{array}{c}-0.014^{* * *} \\
(-3.89)\end{array}$ & $\begin{array}{c}-0.015^{* * *} \\
(-4.08)\end{array}$ & $\begin{array}{c}-0.010^{* * *} \\
(-3.31)\end{array}$ \\
\hline $\begin{array}{l}F C_{i t}^{\frac{1}{10} \text { mile }} \times V P R O_{k}^{\text {ever }} \times V P R O_{t}^{\text {post }} \\
\left(\hat{\theta_{4}}\right)\end{array}$ & $\begin{array}{c}0.038^{* * *} \\
(3.95)\end{array}$ & $\begin{array}{c}0.016^{* * *} \\
(2.78)\end{array}$ & $\begin{array}{c}0.014^{* * *} \\
(2.72)\end{array}$ & $\begin{array}{c}0.014^{* * *} \\
(2.71)\end{array}$ & $\begin{array}{c}0.014^{* *} \\
(2.60)\end{array}$ & $\begin{array}{c}0.010^{* *} \\
(2.44)\end{array}$ \\
\hline $\operatorname{Ln}($ land sqft) & $\begin{array}{l}0.056 \\
(1.37)\end{array}$ & $\begin{array}{c}0.205^{* * *} \\
(14.71)\end{array}$ & $\begin{array}{c}0.206^{* * *} \\
(14.39)\end{array}$ & $\begin{array}{c}0.207^{* * *} \\
(14.30)\end{array}$ & $\begin{array}{c}0.207^{* * *} \\
(14.22)\end{array}$ & $\begin{array}{c}0.212^{* * *} \\
(15.20)\end{array}$ \\
\hline Ln(living sqft.) & $\begin{array}{c}1.024^{* * *} \\
(11.98)\end{array}$ & $\begin{array}{c}0.539^{* * *} \\
(20.39)\end{array}$ & $\begin{array}{c}0.540^{* * *} \\
(20.61)\end{array}$ & $\begin{array}{c}0.531^{* * *} \\
(21.57)\end{array}$ & $\begin{array}{c}0.533^{* * *} \\
(22.09)\end{array}$ & $\begin{array}{c}0.534^{* * *} \\
(21.43)\end{array}$ \\
\hline \# Bedrooms & $\begin{array}{l}-0.018 \\
(-0.72)\end{array}$ & $\begin{array}{c}-0.015^{*} \\
(-1.89)\end{array}$ & $\begin{array}{c}-0.015^{*} \\
(-1.91)\end{array}$ & $\begin{array}{c}-0.013^{*} \\
(-1.75)\end{array}$ & $\begin{array}{c}-0.014^{*} \\
(-1.85)\end{array}$ & $\begin{array}{c}-0.013^{*} \\
(-1.71)\end{array}$ \\
\hline \# Bathrooms & $\begin{array}{c}0.099^{* * *} \\
(5.28)\end{array}$ & $\begin{array}{c}0.067^{* * *} \\
(6.73)\end{array}$ & $\begin{array}{c}0.069^{* * *} \\
(7.01)\end{array}$ & $\begin{array}{c}0.067^{* * *} \\
(6.77)\end{array}$ & $\begin{array}{c}0.067^{* * *} \\
(6.88)\end{array}$ & $\begin{array}{c}0.065^{* * *} \\
(6.55)\end{array}$ \\
\hline Age & $\begin{array}{l}-0.008 \\
(-0.74) \\
\end{array}$ & $\begin{array}{c}-0.020^{* * *} \\
(-3.93) \\
\end{array}$ & $\begin{array}{c}-0.020^{* * *} \\
(-3.67)\end{array}$ & $\begin{array}{c}-0.019^{* * *} \\
(-3.44)\end{array}$ & $\begin{array}{c}-0.019^{* * *} \\
(-3.38)\end{array}$ & $\begin{array}{c}-0.019^{* * *} \\
(-3.78)\end{array}$ \\
\hline Sale qtr. F.E. & $\mathrm{x}$ & $\mathrm{x}$ & $\mathrm{x}$ & $\mathrm{x}$ & $\mathrm{x}$ & $\mathrm{x}$ \\
\hline Sale year F.E. & $\mathrm{x}$ & $\mathrm{x}$ & & & & \\
\hline Sale year-month F.E. & & & & & $\mathrm{x}$ & $\mathrm{x}$ \\
\hline $\begin{array}{l}\text { Border F.E. } \\
\text { Border-by-year F.E. }\end{array}$ & & & & $\mathrm{x}$ & $\mathrm{x}$ & $\mathrm{x}$ \\
\hline County-by-sale year F.E. & & & $\mathrm{x}$ & $\mathrm{x}$ & $\mathrm{x}$ & $\mathrm{x}$ \\
\hline Census tract F.E. & & $\mathrm{x}$ & $\mathrm{x}$ & $\mathrm{x}$ & $\mathrm{x}$ & $\mathrm{x}$ \\
\hline \# Observations & 29,821 & 29,817 & 29,816 & 29,816 & 29,816 & 29,806 \\
\hline$R^{2}$ & 0.62 & 0.82 & 0.82 & 0.82 & 0.83 & 0.83 \\
\hline
\end{tabular}

Notes: All specifications also include dummies for homes with only one bedroom, only one bathroom, missing values, a constant and structure age as a quartic. Sales in the sample are limited to arms-length transactions of single-family homes with 6 or fewer beds and baths in incorporated areas of sufficient population density as described in section 3. Sale prices are trimmed at the 1st and 98th percentiles, and square footages are winsorized at the 1st and 99th percentiles. Borders are limited to pairs of jurisdictions in which one enacts a VPRO and the other does not. Errors are clustered by city. T-statistic are in parentheses. $*, * *, * * *$ denote significance at the 10,5 , and 1 percent level of significance imposing a two-tail test. The underlying data is provided by CoreLogic. 
Table 5: Alternative Border Samples

\begin{tabular}{|c|c|c|c|c|c|c|}
\hline \multirow[b]{2}{*}{ Distance to border: } & \multicolumn{6}{|c|}{ Dependent Variable: Ln(Sale Price) } \\
\hline & $\begin{array}{c}<3 \text { miles } \\
(1)\end{array}$ & $\begin{array}{l}<1 \text { mile } \\
(2)\end{array}$ & $\begin{array}{c}<\frac{1}{2} \text { mile } \\
(3)\end{array}$ & $\begin{array}{c}<\frac{1}{4} \text { mile } \\
(4)\end{array}$ & $<\frac{1}{10}$ mile & $\begin{array}{c}\frac{1}{10}-\frac{1}{2} \text { mile } \\
(6)\end{array}$ \\
\hline$F C_{i t}^{\frac{1}{10} m i l e}(\#$ Foreclosures $)\left(\hat{\theta_{1}}\right)$ & $\begin{array}{l}0.006 \\
(0.95)\end{array}$ & $\begin{array}{l}0.008 \\
(1.42)\end{array}$ & $\begin{array}{c}-0.007^{* *} \\
(-2.25)\end{array}$ & $\begin{array}{c}-0.005^{* *} \\
(-2.04)\end{array}$ & $\begin{array}{c}-0.009^{* *} \\
(-2.38)\end{array}$ & $\begin{array}{l}-0.006 \\
(-1.64)\end{array}$ \\
\hline $\operatorname{VPRO}_{i}^{\text {ever }}(d)$ & $\begin{array}{l}-0.005 \\
(-0.17)\end{array}$ & $\begin{array}{l}0.006 \\
(0.26)\end{array}$ & $\begin{array}{l}0.004 \\
(0.17)\end{array}$ & $\begin{array}{l}0.007 \\
(0.21)\end{array}$ & $\begin{array}{l}-0.010 \\
(-0.26)\end{array}$ & $\begin{array}{l}0.005 \\
(0.21)\end{array}$ \\
\hline $\operatorname{VPRO}_{t}^{\text {post }}(d)$ & $\begin{array}{c}0.056^{* * *} \\
(4.06)\end{array}$ & $\begin{array}{c}0.052^{* * *} \\
(2.90)\end{array}$ & $\begin{array}{l}0.013 \\
(0.76)\end{array}$ & $\begin{array}{l}0.017 \\
(0.91)\end{array}$ & $\begin{array}{l}0.060 \\
(1.68)\end{array}$ & $\begin{array}{l}0.020 \\
(0.90)\end{array}$ \\
\hline $\operatorname{VPRO}_{i}^{\text {ever }} \times V P R O_{t}^{\text {post }}(d)$ & $\begin{array}{c}-0.088^{* * * *} \\
(-3.62)\end{array}$ & $\begin{array}{c}-0.106^{* * *} \\
(-4.30)\end{array}$ & $\begin{array}{c}-0.085^{* * *} \\
(-2.88)\end{array}$ & $\begin{array}{c}-0.086^{* *} \\
(-2.36)\end{array}$ & $\begin{array}{l}-0.072 \\
(-1.39)\end{array}$ & $\begin{array}{c}-0.078^{* * *} \\
(-3.07)\end{array}$ \\
\hline$F C_{i t}^{\frac{1}{10} m i l e} \times V P R O_{k}^{\text {ever }}\left(\hat{\theta_{2}}\right)$ & $\begin{array}{l}-0.010 \\
(-1.49)\end{array}$ & $\begin{array}{c}-0.012^{* *} \\
(-2.05)\end{array}$ & $\begin{array}{l}-0.000 \\
(-0.10)\end{array}$ & $\begin{array}{l}0.001 \\
(0.33)\end{array}$ & $\begin{array}{l}0.006 \\
(1.23)\end{array}$ & $\begin{array}{l}-0.002 \\
(-0.46)\end{array}$ \\
\hline$F C_{i t}^{\frac{1}{10} m i l e} \times V P R O_{k}^{\text {post }}\left(\hat{\theta_{3}}\right)$ & $\begin{array}{c}-0.028^{* * *} \\
(-4.55)\end{array}$ & $\begin{array}{c}-0.029 * * * \\
(-5.66)\end{array}$ & $\begin{array}{c}-0.010^{* * *} \\
(-3.31)\end{array}$ & $\begin{array}{c}-0.010^{* *} \\
(-2.14)\end{array}$ & $\begin{array}{c}-0.011^{* *} \\
(-2.18)\end{array}$ & $\begin{array}{c}-0.011^{* * *} \\
(-3.51)\end{array}$ \\
\hline $\begin{array}{l}F C_{i t}^{\frac{1}{10} m i l e} \times V P R O_{k}^{\text {ever }} \times V P R O_{t}^{\text {post }} \\
\left(\hat{\theta_{4}}\right)\end{array}$ & $\begin{array}{c}0.024^{* * *} \\
(3.08)\end{array}$ & $\begin{array}{c}0.027^{* * *} \\
(4.20)\end{array}$ & $\begin{array}{c}0.010^{* *} \\
(2.44)\end{array}$ & $\begin{array}{l}0.009 \\
(1.54)\end{array}$ & $\begin{array}{l}0.011^{*} \\
(1.75)\end{array}$ & $\begin{array}{c}0.007^{* *} \\
(2.08)\end{array}$ \\
\hline Ln(land sqft.) & $\begin{array}{c}0.191^{* * *} \\
(13.20)\end{array}$ & $\begin{array}{c}0.192^{* * *} \\
(13.41)\end{array}$ & $\begin{array}{c}0.212^{* * *} \\
(15.20)\end{array}$ & $\begin{array}{c}0.224^{* * *} \\
(9.46)\end{array}$ & $\begin{array}{c}0.225^{* * *} \\
(6.34)\end{array}$ & $\begin{array}{c}0.204^{* * *} \\
(15.45)\end{array}$ \\
\hline Ln(living sqft.) & $\begin{array}{c}0.592^{* * *} \\
(20.03)\end{array}$ & $\begin{array}{c}0.573^{* * *} \\
(19.67)\end{array}$ & $\begin{array}{c}0.534^{* * *} \\
(21.43)\end{array}$ & $\begin{array}{c}0.537^{* * *} \\
(15.18)\end{array}$ & $\begin{array}{c}0.524^{* * *} \\
(10.96)\end{array}$ & $\begin{array}{c}0.529^{* * *} \\
(20.94)\end{array}$ \\
\hline \# Bedrooms & $\begin{array}{c}-0.014^{* *} \\
(-2.16)\end{array}$ & $\begin{array}{l}-0.012 \\
(-1.60)\end{array}$ & $\begin{array}{r}-0.013^{*} \\
(-1.71)\end{array}$ & $\begin{array}{l}-0.006 \\
(-0.70)\end{array}$ & $\begin{array}{l}-0.007 \\
(-0.81)\end{array}$ & $\begin{array}{l}-0.013 \\
(-1.53)\end{array}$ \\
\hline \# Baths & $\begin{array}{c}0.073^{* * *} \\
(9.16)\end{array}$ & $\begin{array}{c}0.065^{* * *} \\
(7.35)\end{array}$ & $\begin{array}{c}0.065^{* * *} \\
(6.55)\end{array}$ & $\begin{array}{c}0.060^{* * *} \\
(5.13)\end{array}$ & $\begin{array}{c}0.076^{* * *} \\
(4.59)\end{array}$ & $\begin{array}{c}0.064^{* * *} \\
(6.29)\end{array}$ \\
\hline Age (years) & $\begin{array}{c}-0.013^{* * *} \\
(-3.96) \\
\end{array}$ & $\begin{array}{c}-0.012^{* * *} \\
(-2.84) \\
\end{array}$ & $\begin{array}{c}-0.019^{* * *} \\
(-3.78) \\
\end{array}$ & $\begin{array}{c}-0.021^{* * *} \\
(-3.56) \\
\end{array}$ & $\begin{array}{c}-0.019^{* *} \\
(-2.09) \\
\end{array}$ & $\begin{array}{c}-0.020^{* * *} \\
(-3.50) \\
\end{array}$ \\
\hline Sale year-month F.E. & $\mathrm{x}$ & $\mathrm{x}$ & $\mathrm{x}$ & $\mathrm{x}$ & $\mathrm{x}$ & $\mathrm{x}$ \\
\hline Border-by-year F.E. & $\mathrm{x}$ & $\mathrm{x}$ & $\mathrm{x}$ & $\mathrm{x}$ & $\mathrm{x}$ & $\mathrm{x}$ \\
\hline County-by-sale year F.E. & $\mathrm{x}$ & $\mathrm{x}$ & $\mathrm{x}$ & $\mathrm{x}$ & $\mathrm{x}$ & $\mathrm{x}$ \\
\hline Census tract F.E. & $\mathrm{x}$ & $\mathrm{x}$ & $\mathrm{x}$ & $\mathrm{x}$ & $\mathrm{x}$ & $\mathrm{x}$ \\
\hline $\begin{array}{l}\text { \# Observations } \\
R^{2}\end{array}$ & $\begin{array}{c}62,213 \\
0.82\end{array}$ & $\begin{array}{c}48,098 \\
0.82\end{array}$ & $\begin{array}{c}29,806 \\
0.83\end{array}$ & $\begin{array}{c}15,167 \\
0.84\end{array}$ & $\begin{array}{c}5,865 \\
0.85\end{array}$ & $\begin{array}{c}24,599 \\
0.84\end{array}$ \\
\hline
\end{tabular}

Notes: All specifications also include dummies for homes with only one bedroom, only one bathroom, missing values, a constant and structure age as a quartic. Sales in the sample are limited to arms-length transactions of single-family homes with 6 or fewer beds and baths in incorporated areas of sufficient population density as described in section 3 . Sale prices are trimmed at the 1st and 98th percentiles, and square footages are winsorized at the 1st and 99th percentiles. Borders are limited to pairs of jurisdictions in which one enacts a VPRO and the other does not. Errors are clustered by city. T-statistic are in parentheses. ${ }^{*},{ }^{* *},{ }^{* *}$ denote significance at the 10,5 , and 1 percent level of significance imposing a two-tail test. The underlying data is provided by CoreLogic. 
Table 6: Test for Pre-trends Before VPRO Enactment

\begin{tabular}{|c|c|c|c|c|}
\hline \multirow{3}{*}{ Distance to Border: } & \multicolumn{4}{|c|}{ Dependent Variable: $\operatorname{Ln}($ Sale Price) } \\
\hline & \multicolumn{2}{|c|}{$<\frac{1}{2}$ mile } & \multicolumn{2}{|c|}{$<\frac{1}{4}$ mile } \\
\hline & (1) & $(2)$ & $(3)^{4}$ & (4) \\
\hline$F C_{i t}^{\frac{1}{10} m i l e}$ (\# Foreclosures) & $\begin{array}{c}-0.025^{* * *} \\
(-7.07)\end{array}$ & $\begin{array}{c}-0.021^{* * *} \\
(-5.77)\end{array}$ & $\begin{array}{c}-0.019^{* * *} \\
(-6.17)\end{array}$ & $\begin{array}{c}-0.015^{* * *} \\
(-4.15)\end{array}$ \\
\hline $\operatorname{VPRO}_{i}^{\text {ever }}(d)$ & $\begin{array}{c}-0.058^{* *} \\
(-2.33)\end{array}$ & $\begin{array}{c}-0.059^{* * *} \\
(-2.71)\end{array}$ & $\begin{array}{c}-0.077^{* *} \\
(-2.24)\end{array}$ & $\begin{array}{c}-0.091^{* *} \\
(-2.66)\end{array}$ \\
\hline $\mathrm{VPRO}_{i}^{e v e r} \times \#$ Months before VPRO & $\begin{array}{l}-0.004 \\
(-1.21)\end{array}$ & $\begin{array}{l}-0.003 \\
(-0.72)\end{array}$ & $\begin{array}{l}-0.005 \\
(-1.30)\end{array}$ & $\begin{array}{l}-0.001 \\
(-0.39)\end{array}$ \\
\hline \# Months before VPRO & $\begin{array}{l}-0.002 \\
(-1.56)\end{array}$ & . & $\begin{array}{l}-0.001 \\
(-0.83)\end{array}$ & . \\
\hline$F C_{i t}^{\frac{1}{10} m i l e} \times \#$ Months before VPRO & $\begin{array}{c}0.000^{* * *} \\
(2.71)\end{array}$ & $\begin{array}{c}0.000^{* *} \\
(2.19)\end{array}$ & $\begin{array}{c}0.000^{* *} \\
(2.14)\end{array}$ & $\begin{array}{l}0.000 \\
(1.39)\end{array}$ \\
\hline $\mathrm{VPRO}_{i}^{\text {ever }} \times \#$ Months before VPRO & $\begin{array}{l}0.001 \\
(1.60)\end{array}$ & $\begin{array}{c}0.001 \\
(1.41)\end{array}$ & $\begin{array}{c}0.002^{*} \\
(1.94)\end{array}$ & $\begin{array}{c}0.002^{*} \\
(1.88)\end{array}$ \\
\hline$F C_{i t}^{\frac{1}{10} m i l e} \times V P R O_{k}^{e v e r} \times \#$ Months before VPRO & $\begin{array}{l}0.000 \\
(0.95)\end{array}$ & $\begin{array}{l}0.000 \\
(1.03)\end{array}$ & $\begin{array}{l}0.000 \\
(1.54)\end{array}$ & $\begin{array}{l}0.000 \\
(0.89)\end{array}$ \\
\hline Ln(land sqft.) & $\begin{array}{c}0.175^{* * *} \\
(12.85)\end{array}$ & $\begin{array}{c}0.179^{* * *} \\
(12.88)\end{array}$ & $\begin{array}{c}0.186^{* * *} \\
(10.18)\end{array}$ & $\begin{array}{c}0.194^{* * *} \\
(10.61)\end{array}$ \\
\hline $\operatorname{Ln}$ (living sqft.) & $\begin{array}{c}0.503^{* * *} \\
(21.54)\end{array}$ & $\begin{array}{l}0.497^{* * *} * \\
(22.12)\end{array}$ & $\begin{array}{c}0.519^{* * *} \\
(16.63)\end{array}$ & $\begin{array}{c}0.511^{* * *} \\
(16.30)\end{array}$ \\
\hline \# Bedrooms & $\begin{array}{l}-0.008 \\
(-0.82)\end{array}$ & $\begin{array}{l}-0.007 \\
(-0.80)\end{array}$ & $\begin{array}{l}-0.013 \\
(-1.08)\end{array}$ & $\begin{array}{l}-0.009 \\
(-0.80)\end{array}$ \\
\hline \# Bathrooms & $\begin{array}{c}0.068^{* * *} \\
(7.38)\end{array}$ & $\begin{array}{l}0.070^{* * *} \\
(7.60)\end{array}$ & $\begin{array}{l}0.055^{* * *} \\
(4.63)\end{array}$ & $\begin{array}{l}0.055^{* * *} \\
(5.01)\end{array}$ \\
\hline Age(year) & $\begin{array}{c}-0.017^{* * *} \\
(-3.03) \\
\end{array}$ & $\begin{array}{c}-0.017^{* *} \\
(-2.66)\end{array}$ & $\begin{array}{c}-0.025^{* * *} \\
(-3.88) \\
\end{array}$ & $\begin{array}{c}-0.026^{* * *} \\
(-3.77)\end{array}$ \\
\hline Sale year F.E. & $\mathrm{x}$ & & $\mathrm{x}$ & \\
\hline Sale qtr. F.E. & $\mathrm{x}$ & & $\mathrm{x}$ & \\
\hline Sale year-month F.E. & & $\mathrm{x}$ & & $\mathrm{x}$ \\
\hline Border-by-year F.E. & & $\mathrm{x}$ & & $\mathrm{x}$ \\
\hline County-by-sale year F.E. & & $\mathrm{x}$ & & $\mathrm{x}$ \\
\hline Census Tract F.E. & $\mathrm{x}$ & $\mathrm{x}$ & $\mathrm{x}$ & $\mathrm{x}$ \\
\hline \# Observations & 14,634 & 14,626 & 7,455 & 7,443 \\
\hline$R^{2}$ & 0.81 & 0.83 & 0.82 & 0.84 \\
\hline
\end{tabular}

Notes: All specifications also include dummies for homes with only one bedroom, only one bathroom, missing values, a constant and structure age as a quartic. Sales in the sample are limited to pre-VPRO enactment arms-length transactions of single-family homes with 6 or fewer beds and baths in incorporated areas of sufficient population density as described in section 3 . Sale prices are trimmed at the 1st and 98th percentiles, and square footages are winsorized at the 1st and 99th percentiles. Borders are limited to pairs of jurisdictions in which one enacts a VPRO and the other does not. Errors are clustered by city. T-statistic are in parentheses. ${ }^{*}, * *, * *$ denote significance at the 10,5 , and 1 percent level of significance imposing a two-tail test. The underlying data is provided by CoreLogic. 
Table 7: Robustness Check: Sample Restriction and Placebo Specifications

\begin{tabular}{|c|c|c|c|}
\hline \multirow[t]{3}{*}{ Dependent Variable: Ln(Sale Price) } & \multicolumn{3}{|c|}{ Distance to Border: $<\frac{1}{2}$ Mile } \\
\hline & \multirow{2}{*}{$\begin{array}{c}\text { Sample restriction } \\
>200 \text { sales per border } \\
(1)\end{array}$} & \multicolumn{2}{|c|}{ False border / enactment date } \\
\hline & & 1 mile inside VPRO city & $\begin{array}{c}2 \text { years before enactment } \\
(3)\end{array}$ \\
\hline$F C_{i t}^{\frac{1}{10} m i l e}$ (\# Foreclosures) & $\begin{array}{c}-0.007^{*} \\
(-1.95)\end{array}$ & $\begin{array}{c}-0.004^{*} \\
(-1.96)\end{array}$ & $\begin{array}{c}-0.009^{*} \\
(-1.87)\end{array}$ \\
\hline $\operatorname{VPRO}_{i}^{\text {ever }}(d)$ & $\begin{array}{l}-0.004 \\
(-0.17)\end{array}$ & $\begin{array}{l}0.036 \\
(1.23)\end{array}$ & $\begin{array}{l}-0.035 \\
(-1.66)\end{array}$ \\
\hline $\operatorname{VPRO}_{t}^{\text {post }}(d)$ & $\begin{array}{l}0.015 \\
(0.83)\end{array}$ & $\begin{array}{l}-0.007 \\
(-0.20)\end{array}$ & $\begin{array}{l}0.003 \\
(0.12)\end{array}$ \\
\hline $\mathrm{VPRO}_{i}^{\text {ever }} \times V P R O_{t}^{\text {post }}(d)$ & $\begin{array}{c}-0.102^{* * *} \\
(-2.91)\end{array}$ & $\begin{array}{l}0.031 \\
(0.90)\end{array}$ & $\begin{array}{l}-0.010 \\
(-0.55)\end{array}$ \\
\hline$F C_{i t}^{\frac{1}{10} m i l e} \times V P R O_{k}^{e v e r}$ & $\begin{array}{l}-0.001 \\
(-0.43)\end{array}$ & $\begin{array}{l}0.002 \\
(0.40)\end{array}$ & $\begin{array}{l}0.005 \\
(1.09)\end{array}$ \\
\hline$F C_{i t}^{\frac{1}{10} m i l e} \times V P R O_{t}^{\text {post }}$ & $\begin{array}{c}-0.010^{* * *} \\
(-3.20)\end{array}$ & $\begin{array}{l}-0.005 \\
(-1.55)\end{array}$ & $\begin{array}{c}-0.008^{*} \\
(-1.89)\end{array}$ \\
\hline$F C_{i t}^{\frac{1}{10} \text { mile }} \times V P R O_{k}^{\text {ever }} \times V P R O_{t}^{\text {post }}$ & $\begin{array}{c}0.011^{* * *} \\
(2.83)\end{array}$ & $\begin{array}{c}-0.011^{*} \\
(-1.86)\end{array}$ & $\begin{array}{l}-0.006 \\
(-1.58)\end{array}$ \\
\hline Sale year-month F.E. & $\mathrm{x}$ & $\mathrm{x}$ & $\mathrm{x}$ \\
\hline Border-by-year F.E. & $\mathrm{x}$ & $\mathrm{x}$ & $\mathrm{x}$ \\
\hline County-by-sale year F.E. & $\mathrm{x}$ & $\mathrm{x}$ & $\mathrm{x}$ \\
\hline Census tract F.E. & $\mathrm{x}$ & $\mathrm{x}$ & $\mathrm{x}$ \\
\hline \#Observations & 23,807 & 11,638 & 14,648 \\
\hline$R^{2}$ & 0.83 & 0.84 & 0.83 \\
\hline
\end{tabular}

Notes: Column (1) limits the sample to border pairs with at least 200 sales. Column (2) presents a specification where we create a false border one mile into the VPRO jurisdiction and limit the sample to cities that never passed a VPRO and replicate the specification from column (6) of Table 4. In column (3) we use the the true borders but limit the analysis time to before enactment and instead assume that enactment occurred 2 year before it actually did. All specifications include the full set of controls from column (6) of Table 4 including lot area, home size, dummies for homes with only one bedroom, only one bathroom, missing values, age as a quartic, a constant and fixed effects for tract, sale year-month, county-year, and borderby-year. Sales in the sample are limited to arms-length transactions of single-family homes with 6 or fewer beds and baths in incorporated areas of sufficient population density as described in section 3. Sale prices are trimmed at the 1st and 98th percentiles, and square footages are winsorized at the 1st and 99th percentiles. Borders are limited to pairs of jurisdictions in which one enacts a VPRO and the other does not. Errors are clustered by city. T-statistic are in parentheses. ${ }^{* * *},{ }^{* * *}$ denote significantly different from zero at the 10,5, and 1 percent level of significance imposing a two-tail test. The underlying data is provided by CoreLogic. 
Table 8: Redefining Nearby Foreclosures using only REO Timelines Panel A: Varying the Control Set

\begin{tabular}{|c|c|c|c|c|c|c|}
\hline \multirow[t]{2}{*}{ Distance to Border: } & \multicolumn{6}{|c|}{$<\frac{1}{2}$ Mile } \\
\hline & (1) & (2) & (3) & (4) & (5) & (6) \\
\hline$F C_{i t}^{\frac{1}{10}}$ mile $\left(\hat{\theta_{1}}\right)$ & $\begin{array}{c}-0.054^{* *} \\
(-2.91)\end{array}$ & $\begin{array}{l}-0.021 \\
(-1.80)\end{array}$ & $\begin{array}{l}-0.015 \\
(-1.66)\end{array}$ & $\begin{array}{l}-0.012 \\
(-1.45)\end{array}$ & $\begin{array}{l}-0.008 \\
(-0.96)\end{array}$ & $\begin{array}{l}-0.008 \\
(-0.84)\end{array}$ \\
\hline$F C_{i t}^{\frac{1}{10} m i l e} \times V P R O_{k}^{\text {ever }}\left(\hat{\theta_{2}}\right)$ & $\begin{array}{l}-0.021 \\
(-1.69)\end{array}$ & $\begin{array}{c}-0.017^{* *} \\
(-2.41)\end{array}$ & $\begin{array}{c}-0.017^{* *} \\
(-2.23)\end{array}$ & $\begin{array}{c}-0.019^{* *} \\
(-2.48)\end{array}$ & $\begin{array}{c}-0.018^{* *} \\
(-2.45)\end{array}$ & $\begin{array}{l}-0.012 \\
(-1.61)\end{array}$ \\
\hline$F C_{i t}^{\frac{1}{10} m i l e} \times V P R O_{t}^{\text {post }}\left(\hat{\theta_{3}}\right)$ & $\begin{array}{c}-0.045^{* *} \\
(-2.37)\end{array}$ & $\begin{array}{c}-0.028^{* *} \\
(-2.24)\end{array}$ & $\begin{array}{c}-0.031^{* *} \\
(-2.72)\end{array}$ & $\begin{array}{c}-0.033^{* *} \\
(-3.02)\end{array}$ & $\begin{array}{c}-0.038^{* * *} \\
(-3.42)\end{array}$ & $\begin{array}{c}-0.028^{* *} \\
(-2.25)\end{array}$ \\
\hline$F C_{i t}^{\frac{1}{10} m i l e} \times V P R O_{k}^{\text {ever }} \times V P R O_{t}^{\text {post }}\left(\hat{\theta_{4}}\right)$ & $\begin{array}{c}0.118^{* * *} \\
(10.10)\end{array}$ & $\begin{array}{c}0.062^{* * *} \\
(11.70)\end{array}$ & $\begin{array}{c}0.059^{* * *} \\
(9.38)\end{array}$ & $\begin{array}{c}0.061^{* * *} \\
(9.71)\end{array}$ & $\begin{array}{c}0.060^{* * *} \\
(10.35)\end{array}$ & $\begin{array}{c}0.045^{* * *} \\
(6.88)\end{array}$ \\
\hline Sale qtr. F.E. & $\mathrm{x}$ & $\mathrm{x}$ & $\mathrm{x}$ & $\mathrm{x}$ & $\mathrm{x}$ & $\mathrm{x}$ \\
\hline $\begin{array}{l}\text { Sale year F.E. } \\
\text { Sale vear-month F.E. }\end{array}$ & $\mathrm{x}$ & $\mathrm{x}$ & & & $\mathrm{x}$ & $\mathrm{x}$ \\
\hline $\begin{array}{l}\text { Border F.E. } \\
\text { Border-by-year F.E. }\end{array}$ & & & & $\mathrm{x}$ & $\mathrm{x}$ & $\mathrm{x}$ \\
\hline $\begin{array}{l}\text { County-by-sale year F.E. } \\
\text { Census tract F.E. }\end{array}$ & & $\mathrm{x}$ & $\begin{array}{l}\mathrm{x} \\
\mathrm{x}\end{array}$ & $\begin{array}{l}\mathrm{x} \\
\mathrm{x}\end{array}$ & $\begin{array}{l}\mathrm{x} \\
\mathrm{x}\end{array}$ & $\begin{array}{l}\mathrm{x} \\
\mathrm{x}\end{array}$ \\
\hline $\begin{array}{l}\text { \# Observations } \\
R^{2}\end{array}$ & $\begin{array}{c}29,821 \\
0.62\end{array}$ & $\begin{array}{c}29,817 \\
0.81\end{array}$ & $\begin{array}{c}29,816 \\
0.82\end{array}$ & $\begin{array}{c}29,816 \\
0.82\end{array}$ & $\begin{array}{c}29,816 \\
0.82\end{array}$ & $\begin{array}{c}29,806 \\
0.83\end{array}$ \\
\hline
\end{tabular}

Panel B: Varying Distance to the Border

\begin{tabular}{|c|c|c|c|c|c|c|}
\hline Distance to border: & $\begin{array}{c}<3 \text { miles } \\
(1)\end{array}$ & $\begin{array}{c}<1 \text { mile } \\
(2)\end{array}$ & $\begin{array}{c}<\frac{1}{2} \text { mile } \\
(3)\end{array}$ & $\begin{array}{c}<\frac{1}{4} \text { mile } \\
(4)\end{array}$ & $\begin{array}{c}<\frac{1}{10} \text { mile } \\
(5)\end{array}$ & $\begin{array}{c}\frac{1}{10}-\frac{1}{4} \text { miles } \\
(6)\end{array}$ \\
\hline$F C_{i t}^{\frac{1}{10} m i l e}\left(\hat{\theta_{1}}\right)$ & $\begin{array}{l}0.016 \\
(0.61)\end{array}$ & $\begin{array}{l}0.022 \\
(0.80)\end{array}$ & $\begin{array}{l}-0.008 \\
(-0.84)\end{array}$ & $\begin{array}{l}-0.006 \\
(-0.72)\end{array}$ & $\begin{array}{l}-0.015 \\
(-0.97)\end{array}$ & $\begin{array}{l}-0.005 \\
(-0.68)\end{array}$ \\
\hline$F C_{i t}^{\frac{1}{10} m i l e} \times V P R O_{k}^{\text {ever }}\left(\hat{\theta_{2}}\right)$ & $\begin{array}{l}-0.035 \\
(-1.29)\end{array}$ & $\begin{array}{l}-0.043 \\
(-1.41)\end{array}$ & $\begin{array}{l}-0.012 \\
(-1.61)\end{array}$ & $\begin{array}{l}-0.005 \\
(-0.56)\end{array}$ & $\begin{array}{l}0.009 \\
(0.44)\end{array}$ & $\begin{array}{c}-0.014^{*} \\
(-2.14)\end{array}$ \\
\hline$F C_{i t}^{\frac{1}{10} m i l e} \times V P R O_{t}^{\text {post }}\left(\hat{\theta_{3}}\right)$ & $\begin{array}{l}-0.057 \\
(-1.72)\end{array}$ & $\begin{array}{c}-0.067^{*} \\
(-2.00)\end{array}$ & $\begin{array}{c}-0.028^{* *} \\
(-2.25)\end{array}$ & $\begin{array}{c}-0.031^{* *} \\
(-2.79)\end{array}$ & $\begin{array}{l}-0.022 \\
(-1.39)\end{array}$ & $\begin{array}{c}-0.031^{* *} \\
(-2.60)\end{array}$ \\
\hline$F C_{i t}^{\frac{1}{10} m i l e} \times V P R O_{k}^{\text {ever }} \times V P R O_{t}^{\text {post }}\left(\hat{\theta_{4}}\right)$ & $\begin{array}{c}0.074^{*} \\
(1.84) \\
\end{array}$ & $\begin{array}{c}0.085^{*} \\
(2.11)\end{array}$ & $\begin{array}{c}0.045^{* * *} \\
(6.88) \\
\end{array}$ & $\begin{array}{c}0.041^{* * * *} \\
(4.58)\end{array}$ & $\begin{array}{l}0.027 \\
(1.27) \\
\end{array}$ & $\begin{array}{c}0.042^{* * *} \\
(7.44)\end{array}$ \\
\hline Sale year-month F.E. & $\mathrm{x}$ & $\mathrm{x}$ & $\mathrm{x}$ & $\mathrm{x}$ & $\mathrm{x}$ & $\mathrm{x}$ \\
\hline Border-by-year F.E. & $\mathrm{x}$ & $\mathrm{x}$ & $\mathrm{x}$ & $\mathrm{x}$ & $\mathrm{x}$ & $\mathrm{x}$ \\
\hline County-by-sale year F.E. & $\mathrm{x}$ & $\mathrm{x}$ & $\mathrm{x}$ & $\mathrm{x}$ & $\mathrm{x}$ & $\mathrm{x}$ \\
\hline Census tract F.E. & $\mathrm{x}$ & $\mathrm{x}$ & $\mathrm{x}$ & $\mathrm{x}$ & $\mathrm{x}$ & $\mathrm{x}$ \\
\hline $\begin{array}{l}\text { \# Observations } \\
R^{2}\end{array}$ & $\begin{array}{c}62,213 \\
0.82\end{array}$ & $\begin{array}{c}48,098 \\
0.82\end{array}$ & $\begin{array}{c}29,806 \\
0.83\end{array}$ & $\begin{array}{c}15,167 \\
0.83\end{array}$ & $\begin{array}{c}5,865 \\
0.83\end{array}$ & $\begin{array}{c}24,599 \\
0.83\end{array}$ \\
\hline
\end{tabular}

Notes: This table replicates the specifications from Tables 4 and 5, but considers only properties that are real-estate owned (REO) in constructing the independent variable of interest, the number of nearby foreclosures, $F C_{i t}^{\frac{1}{10}}$ mile . The dependent variable is the logarithm of the transaction price associated with non-distressed, arms-length sales. Standard errors are clustered by border-pair. T-statistic are in parentheses. ${ }^{*},{ }^{*}, * * *$ denote significance at the 10,5 , and 1 percent level of significance imposing a two-tail test. The underlying data is provided by 36 reLogic. 
Table 9: Sales out of REO

\begin{tabular}{|c|c|c|c|c|c|c|}
\hline \multirow[b]{2}{*}{ Distance to border: } & \multicolumn{6}{|c|}{ Dependent Variable: Ln(Sale Price) } \\
\hline & $\begin{array}{c}<3 \text { miles } \\
(1)\end{array}$ & $\begin{array}{c}<1 \text { mile } \\
(2)\end{array}$ & $<\frac{1}{2}$ mile & $<\frac{1}{4}$ mile & $<\frac{1}{10}$ mile & $\frac{1}{10}-\frac{1}{2}$ mile \\
\hline $\operatorname{REO}_{i t}^{\text {sale }}\left(\hat{\beta}_{1}\right)(d)$ & $\begin{array}{c}-0.258^{* * *} \\
(-7.67)\end{array}$ & $\begin{array}{c}-0.261^{* * *} \\
(-8.36)\end{array}$ & $\begin{array}{c}-0.243^{* * *} \\
(-8.31)\end{array}$ & $\begin{array}{c}-0.232^{* * *} \\
(-6.84)\end{array}$ & $\begin{array}{c}-0.213^{* * *} \\
(-6.26)\end{array}$ & $\begin{array}{c}-0.244^{* * *} \\
(-8.48)\end{array}$ \\
\hline $\operatorname{VPRO}_{i}^{\text {ever }}(d)$ & $\begin{array}{l}-0.007 \\
(-0.27)\end{array}$ & $\begin{array}{l}0.001 \\
(0.06)\end{array}$ & $\begin{array}{l}0.019 \\
(0.71)\end{array}$ & $\begin{array}{l}0.030 \\
(0.90)\end{array}$ & $\begin{array}{l}0.024 \\
(0.57)\end{array}$ & $\begin{array}{l}0.012 \\
(0.50)\end{array}$ \\
\hline $\operatorname{VPRO}_{t}^{\text {post }}(d)$ & $\begin{array}{l}-0.019 \\
(-1.64)\end{array}$ & $\begin{array}{c}-0.031^{* *} \\
(-2.28)\end{array}$ & $\begin{array}{c}-0.037^{* *} \\
(-2.34)\end{array}$ & $\begin{array}{l}-0.015 \\
(-0.75)\end{array}$ & $\begin{array}{l}-0.008 \\
(-0.29)\end{array}$ & $\begin{array}{l}-0.032 \\
(-1.60)\end{array}$ \\
\hline $\mathrm{VPRO}_{i}^{\text {ever }} \times V P R O_{t}^{\text {post }}$ & $\begin{array}{l}-0.027 \\
(-1.35)\end{array}$ & $\begin{array}{l}-0.036 \\
(-1.48)\end{array}$ & $\begin{array}{l}-0.048 \\
(-1.67)\end{array}$ & $\begin{array}{c}-0.067^{* *} \\
(-2.04)\end{array}$ & $\begin{array}{l}-0.050 \\
(-1.06)\end{array}$ & $\begin{array}{c}-0.049^{*} \\
(-1.81)\end{array}$ \\
\hline $\mathrm{REO}_{i t}^{\text {sale }} \times \operatorname{VPRO} \mathrm{i}_{i}^{\text {ever }}\left(\hat{\beta}_{2}\right)$ & $\begin{array}{l}-0.020 \\
(-0.87)\end{array}$ & $\begin{array}{l}-0.030 \\
(-1.37)\end{array}$ & $\begin{array}{c}-0.063^{* *} \\
(-2.39)\end{array}$ & $\begin{array}{c}-0.086^{* * *} \\
(-2.69)\end{array}$ & $\begin{array}{l}-0.065 \\
(-1.35)\end{array}$ & $\begin{array}{c}-0.067^{* *} \\
(-2.59)\end{array}$ \\
\hline $\mathrm{REO}_{i t}^{\text {sale }} \times V P R O_{t}^{\text {post }}\left(\hat{\beta}_{3}\right)$ & $\begin{array}{c}0.048^{* *} \\
(2.52)\end{array}$ & $\begin{array}{c}0.050^{* *} \\
(2.19)\end{array}$ & $\begin{array}{c}0.054^{* *} \\
(2.26)\end{array}$ & $\begin{array}{l}0.032 \\
(1.17)\end{array}$ & $\begin{array}{l}0.007 \\
(0.27)\end{array}$ & $\begin{array}{c}0.062^{* *} \\
(2.42)\end{array}$ \\
\hline $\mathrm{REO}_{i t}^{\text {sale }} \times V P R O_{i}^{\text {ever }} \times V P R O_{t}^{\text {post }}\left(\hat{\beta}_{4}\right)$ & $\begin{array}{c}0.046^{*} \\
(1.74)\end{array}$ & $\begin{array}{c}0.057^{*} \\
(1.86)\end{array}$ & $\begin{array}{c}0.062^{*} \\
(1.83)\end{array}$ & $\begin{array}{c}0.111^{* * *} \\
(3.05)\end{array}$ & $\begin{array}{c}0.114^{* *} \\
(2.07)\end{array}$ & $\begin{array}{l}0.054 \\
(1.55)\end{array}$ \\
\hline Ln(land sqft.) & $\begin{array}{c}0.190^{* * *} \\
(15.55)\end{array}$ & $\begin{array}{c}0.195^{* * *} \\
(14.89)\end{array}$ & $\begin{array}{c}0.222^{* * *} \\
(17.47)\end{array}$ & $\begin{array}{c}0.233^{* * *} \\
(11.57)\end{array}$ & $\begin{array}{c}0.240^{* * *} \\
(8.63)\end{array}$ & $\begin{array}{c}0.214^{* * *} \\
(17.41)\end{array}$ \\
\hline Ln(living sqft.) & $\begin{array}{c}0.636^{* * *} \\
(20.15)\end{array}$ & $\begin{array}{c}0.618^{* * *} \\
(19.33)\end{array}$ & $\begin{array}{c}0.567^{* * * *} \\
(23.13)\end{array}$ & $\begin{array}{c}0.557^{* * *} \\
(17.72)\end{array}$ & $\begin{array}{c}0.580^{* * *} \\
(12.99)\end{array}$ & $\begin{array}{c}0.554^{* * *} \\
(23.38)\end{array}$ \\
\hline \# Bedrooms & $\begin{array}{c}-0.011^{*} \\
(-1.74)\end{array}$ & $\begin{array}{l}-0.010 \\
(-1.27)\end{array}$ & $\begin{array}{l}-0.011 \\
(-1.40)\end{array}$ & $\begin{array}{l}-0.009 \\
(-1.02)\end{array}$ & $\begin{array}{c}-0.016^{*} \\
(-1.88)\end{array}$ & $\begin{array}{l}-0.008 \\
(-0.88)\end{array}$ \\
\hline \# Bathrooms & $\begin{array}{c}0.059^{* * *} \\
(7.78)\end{array}$ & $\begin{array}{c}0.057^{* * *} \\
(6.96)\end{array}$ & $\begin{array}{c}0.053^{* * *} \\
(5.28)\end{array}$ & $\begin{array}{c}0.045^{* * *} \\
(4.23)\end{array}$ & $\begin{array}{c}0.056^{* * *} \\
(3.44)\end{array}$ & $\begin{array}{c}0.054^{* * *} \\
(5.29)\end{array}$ \\
\hline Age (year) & $\begin{array}{c}-0.012^{* * *} \\
(-3.80)\end{array}$ & $\begin{array}{c}-0.014^{* * *} \\
(-3.49)\end{array}$ & $\begin{array}{c}-0.019^{* * *} \\
(-3.98)\end{array}$ & $\begin{array}{c}-0.021^{* * *} \\
(-3.62)\end{array}$ & $\begin{array}{c}-0.023^{* *} \\
(-2.36)\end{array}$ & $\begin{array}{c}-0.020 * * * \\
(-3.46)\end{array}$ \\
\hline Sale year-month F.E. & $\mathrm{x}$ & $\mathrm{x}$ & $\mathrm{x}$ & $\mathrm{x}$ & $\mathrm{x}$ & $\mathrm{x}$ \\
\hline Border-by-year F.E. & $\mathrm{x}$ & $\mathrm{x}$ & $\mathrm{x}$ & $\mathrm{x}$ & $\mathrm{x}$ & $\mathrm{x}$ \\
\hline County-by-sale year F.E. & $\mathrm{x}$ & $\mathrm{x}$ & $\mathrm{x}$ & $\mathrm{x}$ & $\mathrm{x}$ & $\mathrm{x}$ \\
\hline Census tract F.E. & $\mathrm{x}$ & $\mathrm{x}$ & $\mathrm{x}$ & $\mathrm{x}$ & $\mathrm{x}$ & $\mathrm{x}$ \\
\hline $\begin{array}{l}\# \text { Observations } \\
R^{2}\end{array}$ & $\begin{array}{c}81,935 \\
0.83\end{array}$ & $\begin{array}{c}62,906 \\
0.83\end{array}$ & $\begin{array}{c}39,299 \\
0.84\end{array}$ & $\begin{array}{c}20,241 \\
0.85\end{array}$ & $\begin{array}{l}7,886 \\
0.86\end{array}$ & $\begin{array}{c}3,2277 \\
0.84\end{array}$ \\
\hline
\end{tabular}

Notes: This table replicates the specifications from Tables 4 and 5, but considers only properties that the mortgage servicers (banks) own (real-estate owned, (REO)) in constructing the independent variables of interest, $F C_{i t}^{\frac{1}{10}}$ mile . The dependent variable is the logarithm of the transaction price associated with non-distressed, arms-length sales. Standard errors are clustered by border-pair. T-statistic are in parentheses. ${ }^{*}, * * * * *$ denote significance at the 10,5 , and 1 percent level of significance imposing a two-tail test. The underlying data is provided by CoreLogic. 


\section{Online Appendix (NOT FOR PUBLICATION)}

This appendix accompanies "Do Vacant Property Registrations Ameliorate Foreclosure Externalities?" by Biswas, Cunningham, Gerardi, and Sexton. Below is a list of tables/figures and brief descriptions of their contents.

- Table A.1 Provides a list of all Florida cities that enacted a VPRO through April 2012, and the exact date of enactment by each city. In addition, the table identifies the specific cities that are included in the estimation sample.

- TableA.2 Displays summary statistics of property characteristics broken down by VPRO/non-VPRO status and shows how differences in those characteristics changes as we change the border buffer threshold. 
Table A.1: Cities that enacted a Vacant Property Ordinance in Florida Appendix: Florida VPRO Enactment Dates

\begin{tabular}{|c|c|c|c|}
\hline Locality & Date Enacted & Locality & Date Enacted \\
\hline Miami* & $10 / 16 / 2008$ & Oakland Park* & $2 / 3 / 2010$ \\
\hline Palm Bay & $11 / 20 / 2008$ & Lake Mary & $12 / 16 / 2010$ \\
\hline Cutler Bay* & $9 / 17 / 2008$ & Port Richie & $2 / 9 / 2010$ \\
\hline Coral Springs & $6 / 3 / 2008$ & Homestead & $9 / 22 / 2010$ \\
\hline Parkland & $9 / 29 / 2008$ & Ocala & $4 / 20 / 2010$ \\
\hline Margate & $7 / 2 / 2008$ & Florida City & $1 / 12 / 2010$ \\
\hline Deerfield Beach* & $8 / 19 / 2008$ & Palm Beach* & $7 / 13 / 2010$ \\
\hline Treasure Island* & $12 / 6 / 2008$ & Lantana* & $12 / 13 / 2010$ \\
\hline North Lauderdale* & $1 / 8 / 2008$ & Dania Beach & $1 / 26 / 2010$ \\
\hline Sunny Isles Beach & $5 / 15 / 2008$ & Hollywood & $1 / 20 / 2010$ \\
\hline Coconut Creek & $10 / 23 / 2008$ & Apopka & $8 / 4 / 2010$ \\
\hline Tamarac & $10 / 22 / 2008$ & Miami Gardens & $9 / 8 / 2010$ \\
\hline Cape Coral & $12 / 15 / 2008$ & Pahokee & $7 / 13 / 2010$ \\
\hline Cooper City & 4/14/2009 & Pembroke Pines & $3 / 17 / 2010$ \\
\hline Maitland* & $6 / 8 / 2009$ & Indian Rock Beach* & $5 / 25 / 2010$ \\
\hline Belleview & $12 / 15 / 2009$ & Lauderdale-By-The-Sea* & $9 / 14 / 2010$ \\
\hline Winter Haven* & $9 / 28 / 2009$ & Fort Myers & $1 / 4 / 2010$ \\
\hline Fruitland Park & $7 / 31 / 2009$ & Punta Gorda & $4 / 21 / 2010$ \\
\hline Pompano Beach & $9 / 8 / 2009$ & West Palm Beach* & $6 / 14 / 2010$ \\
\hline Lady Lake & $9 / 23 / 2009$ & New Smyrna Beach* & $5 / 25 / 2010$ \\
\hline Macclenny & $5 / 12 / 2009$ & Jacksonville* & $5 / 25 / 2010$ \\
\hline Minneola* & $2 / 17 / 2009$ & Lake Worth & $9 / 7 / 2010$ \\
\hline Daytona Beach* & $11 / 18 / 2009$ & Palm Coast & $2 / 3 / 2010$ \\
\hline Rockledge & 10/7/2009 & Virginia Gardens & $10 / 21 / 2010$ \\
\hline Pinellas Park & $12 / 10 / 2009$ & North Miami* & $6 / 22 / 2010$ \\
\hline Titusville & $12 / 8 / 2009$ & Ormond Beach & $4 / 20 / 2010$ \\
\hline West Melbourne* & $11 / 17 / 2009$ & Wilton Manors & $4 / 27 / 2010$ \\
\hline Melbourne Beach* & $2 / 18 / 2009$ & Coral Gables* & $6 / 7 / 2011$ \\
\hline North Port & $3 / 9 / 2009$ & Port Orange & $12 / 13 / 2011$ \\
\hline Casselberry & $12 / 14 / 2009$ & Grant-Valkaria* & $3 / 9 / 2011$ \\
\hline Palm Shores & $7 / 28 / 2009$ & Pinecrest & $12 / 13 / 2011$ \\
\hline Bay Harbor Islands & $9 / 14 / 2009$ & Lake Park & 9/7/2011 \\
\hline North Palm Beach & $5 / 14 / 2009$ & Groveland* & 4/4/2011 \\
\hline Redington Beach* & 4/7/2009 & Cocoa & $8 / 17 / 2011$ \\
\hline Tampa* & $12 / 17 / 2009$ & Sunrise* & $1 / 25 / 2011$ \\
\hline St. Pete Beach & $10 / 27 / 2009$ & New Port Richey & $5 / 3 / 2011$ \\
\hline Sanford & $6 / 22 / 2009$ & Loxahatchee Groves & $7 / 5 / 2011$ \\
\hline Davie* & $1 / 7 / 2009$ & Belle Isle* & $1 / 4 / 2011$ \\
\hline Boynton Beach* & $9 / 14 / 2009$ & Royal Palm Beach & $4 / 21 / 2011$ \\
\hline Melbourne & $2 / 10 / 2009$ & Eagle Lake & $2 / 7 / 2011$ \\
\hline Belleair* & $8 / 4 / 2009$ & Port St Lucie & $3 / 26 / 2012$ \\
\hline Kissimmee & $11 / 16 / 2010$ & & \\
\hline
\end{tabular}

Notes: *Denotes VPRO cities used in the analysis. We limit the sample to cities that share at least one border with a non-VPRO city and thus exclude cities bounded entirely by unincorporated land (or water) and cities that are completely surround by jurisdictions that enacted a VPRO. 


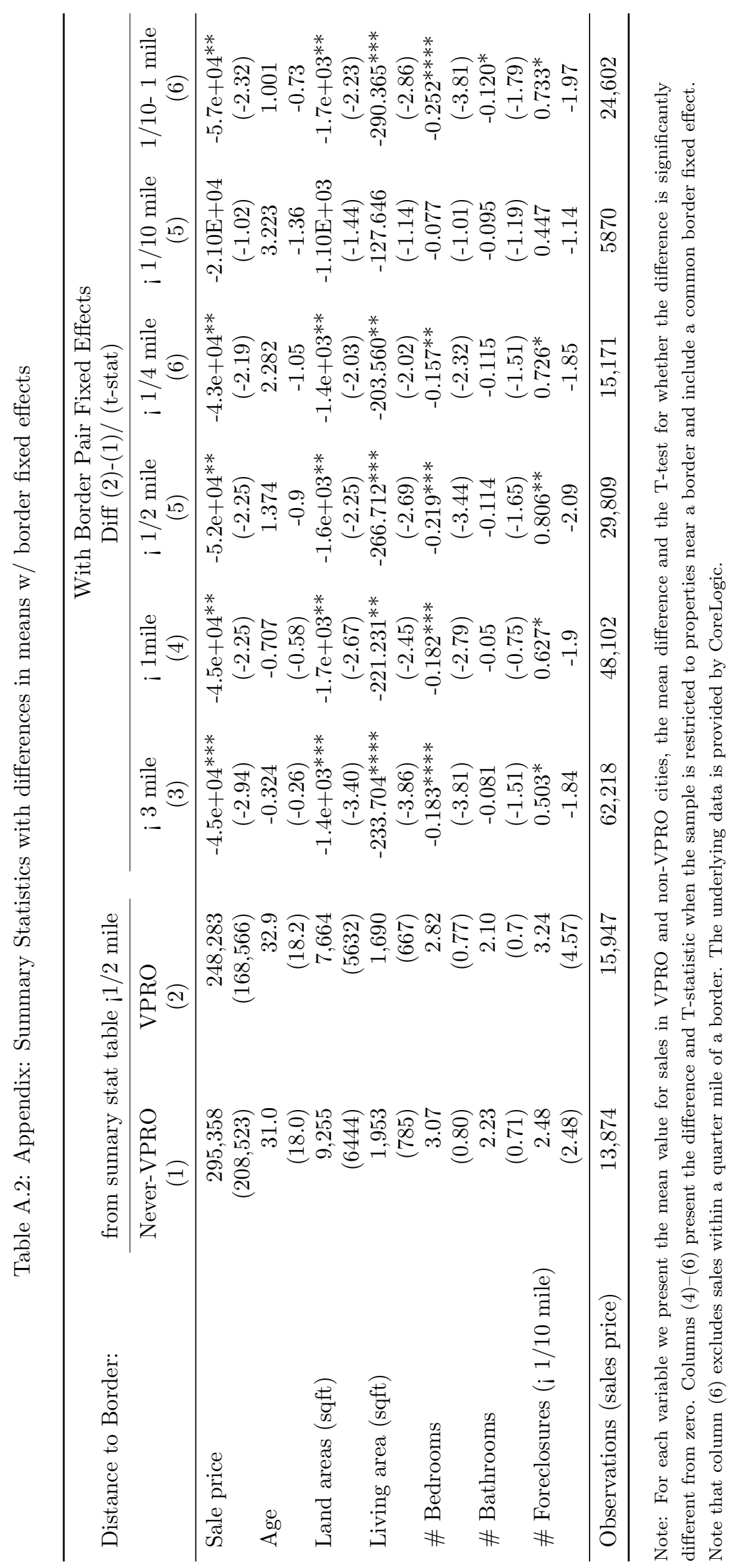

